\title{
Trophic Ecology and Structure of Coastal Antarctic Fish Communities
}

\author{
Timothy E. Targett* \\ Department of Zoology, University of Maine, Orono, Maine 04469, USA
}

\begin{abstract}
The trophic ecology and structure of 5 benthic Antarctic fish communities were studied. Two locations at South Georgia Island, one at the South Sandwich Islands, and two at the South Orkney Islands were sampled using a bottom trawl. Species diversity was low with 13 or fewer species in each community and a pronounced dominance of 3 or fewer species per community. $H^{\prime}$ diversity values were $<1.3$ in all cases and $<0.8$ in 3 ; e evenness values were $<0.6$ in all cases and $<0.3$ in 3 . The South Sandwich Island community had the lowest species diversity $\left(H^{\prime}=0.2\right)$, likely due to a very limited prey spectrum geographic isolation, geologically recent formation, and volcanic origin which formed only a narrow shelf zone where coastal fish communities could develop. The dominant species in all communities were one or more of the nototheniid fishes Notothenia larseni, $N$. gibberifrons, $N$. nudifrons, and $N$. angustifrons. Food resource partitioning was evident within communities at a general taxonomic category level of prey identification. Dominant species within communities generally are morphologically and behaviorally adapted to feed at different levels along a vertical prey-distribution axis. $N$. larseni feeds above the bottom. $N$. gibberifrons and $N$. nudifrons feed on benthos, $N$. gibberifrons preys more on infauna, and $N$. nudifrons more on epifauna. $N$. angustifrons is also a benthos feeder but takes somewhat different prey than the other two species. Low fish species diversity precludes the necessity for fine division of food resources within vertical habitat zones. Feeding niche differences, likely evolved by nototheniids as an adaptation to avoid competition for prey, may contribute to the success and dominance of nototheniid species in these communities. Nearly all cases of high prey overlap were cases involving non-dominant species, and in which krill (Euphausia superba) was important for both species. Krill is a very abundant prey resource in the Antarctic, particularly during austral summer and fall, minimizing competition for this prey among channichthyids and nototheniids. The South Sandwich Island community had a prey spectrum consisting almost entirely of only 3 gammaridean amphipod species. This lowdiversity prey spectrum is probably due to the unstable volcanic rock and cinder bottom type, which does not support a well developed benthic invertebrate fauna. Competition for amphipods likely was great and low fish diversity reflects the low prey resource diversity. Daily rations, calculated in terms of dry prey biomass, for $N$ angustifrons, $N$. gibberifrons, and $N$. larseni were between 0.24 and $2.03 \%$ dry body weight, depending on mean prey weight in stomachs and gastric evacuation rate for each species. Krill was an important food resource for $N$. larseni, Champsocephalus gunneri, Trematomus newnesi, and Chaenocephalus aceratus. Based on small sample sizes, T hansoni, Champsocephalus esox, and Pseudochaenichthys georgianus also appear to prey heavily on E. superba. At one South Georgia Island community essentially all fishes preyed substantially on krill, suggesting that even fishes with benthic feeding modes take advantage of abundant krill resources when available close to the bottom.
\end{abstract}

\section{INTRODUCTION}

The Antarctic Region has been isolated geographically since Antarctica separated from Australia in the Cretaceous or early Cenozoic 40-65 million years ago. The coastal areas south of the Antarctic Convergence (generally between $50^{\circ}$ and $60^{\circ} \mathrm{S}$ ) are nearly $900 \mathrm{~km}$ from the nearest land mass to the north. Waters south of the Convergence are colder and thermally more stable than those to the north, and surface currents on both sides of the Convergence flow generally northward, away from Antarctica (DeWitt, 1971).

- Present address: Skidaway Institute of Oceanography, P.O. Box 13687, Savannah, Georgia 31406, USA
Research expeditions into the Antarctic, beginning in the mid 1800's collected fishes and provided specimens for species descriptions. We now have a good understanding of the general nature of the Antarctic coastal fish fauna in terms of species composition and general zoogeography (see reviews by Andriashev, 1965; DeWitt, 1971; Permitin, 1977). DeWitt (1971) lists 110 fish species from 14 families in the coastal Antarctic Region.

The original notothenioid fish fauna, present when Antarctica separated from Australia, has undergone an evolutionary radiation. Because of the isolation of the Antarctic, this radiation has occurred with essentially no exchange of fishes with fauna outside the Antarctic. As a result, although the coastal fish fauna includes 
representatives of 14 families, more than $70 \%$ of the species and greater than $90 \%$ of the individuals belong to four families in the suborder Notothenioidei: Nototheniidae (Antarctic cods), Bathydraconidae (dragon fishes), Channichthyidae (ice fishes), and Harpagiferidae (plunder fishes), nearly all rather sedentary benthic forms (DeWitt, 1971). Furthermore, $95 \%$ of the species of Notothenioidei are endemic to the Antarctic Region. Nearly $70 \%$ of the non-notothenioid fishes (which comprise $25 \%$ of Antarctic coastal fish species) are also endemic. These likely represent occasional successful invasions by fishes from more northerly families, which subsequently evolved in the Antarctic.

Antarctic coastal fish communities, therefore, are unique. The niches in these communities are occupied primarily by species not present in the rest of the world. The communities are structurally and functionally the result of millions of years of coadaptation and coevolution of the original notothenioid fish fauna.

Andriashev (1965) noted that essentially no research had been devoted to the feeding ecology of Antarctic fishes. Since then, only approximately 20 research papers have been published which contain information on the feeding biology of Antarctic fishes. In nearly half of these papers, discussions of food habits are limited to qualitative observations, generally on a limited number of specimens (Hureau, 1964; Holloway, 1969; Tomo, 1969; Permitin, 1970; Meier, 1971; Yukhov, 1971; Rakusa-Suszczewski and Piasek, 1973; Heywood and Light, 1975; McCleave et al., 1977; Moreno, 1980). Investigations which have looked in more detail at the feeding biology of Antarctic fishes report the food habits of specimens collected at various times and often from widely separated geographic areas grouped together for analysis (Arnaud and Hureau, 1966; Hureau, 1966, 1970; Permitin and Tarverdiyeva, 1972, 1978; Tarverdiyeva, 1972; Richardson, 1975; DeWitt and Hopkins, 1977; Moreno and Osorio, 1977; Showers et al., 1977; Daniels, in press; Wyanski and Targett, in press). This type of investigation gives information on the general feeding biology or feeding niche of individual species, but gives no information on food resource partitioning or interactions among fishes within communities obtaining prey from the same food resource base. Furthermore, nearly half of these studies used percentage frequency of occurrence to describe the importance of various prey. This method overemphasizes the importance of small prey and does not accurately describe the importance of particular prey groups, in terms of biomass. Most of these studies also give little information on dietary changes accompanying growth. Only 6 studies have compared the feeding biology of more than 2 species captured in even the same general geographic area, and only 3 used a method of stomach content analysis other than percentage frequency of occurrence. Arnaud and Hureau (1966) reported the food habits of 3 species from Adelie Land $\left(66^{\circ} 40^{\prime} \mathrm{S}, 140^{\circ} 1^{\prime} \mathrm{E}\right)$ and Hureau (1970) investigated 3 more species from the Kerguelen Islands $\left(49^{\circ} 30^{\prime} \mathrm{S}, 69^{\circ} 30^{\prime} \mathrm{E}\right)$. Both locations are in the East Antarctic and all 6 species are in the family Nototheniidae. Daniels (in press) described the diets of 12 species collected along the Antarctic Peninsula at 24 sites from Terra Firma Islands, Margurite Bay $\left(68^{\circ} 42^{\prime} \mathrm{S}, 67^{\circ} 32^{\prime} \mathrm{W}\right)$ to Admiralty Bay, King George $\mathrm{V}$ Island $\left(62^{\circ} 10^{\prime} \mathrm{S}, 58^{\circ} 25^{\prime} \mathrm{W}\right)$. The species examined included 8 nototheniids, 2 harpagiferids, and 2 bathydraconids.

A detailed study of the trophic ecology and structure of coastal Antarctic fish communities is needed to develop an understanding of structural and functional aspects of these communities. An investigation of this kind is particularly important in the light of increased human impact on the Antarctic marine ecosystem, an ecosystem being directly influenced by the commercial harvesting of fishes, krill, seals, and whales. The USSR, for example, has recently developed a fishery for nototheniid fishes with annual catches of 200,000 to 300,000 tons (Laws, 1977). Additional impacts on the ecosystem result indirectly from the effects of harvesting operations, shipping traffic, and generally increasing human activity on local environments (US Department of State, 1978).

The present study investigates several aspects of the community ecology of coastal Antarctic fishes, presenting detailed information on (1) species composition and relative number and biomass of individuals in various fish communities, (2) the prey resources which support the fish community at each location, (3) the prey groups which are most important for each fish species, (4) breadth of the prey spectrum for each fish species, (5) changes in food habits accompanying growth, (6) diel changes in feeding intensity, (7) where, within the community habitat, each species feeds, (8) the degree of feeding niche overlap between fish species within a community and how food resources are partitioned, and (9) how resource allocation patterns change with different species composition at different locations, depths, and bottom types. In addition, data on mean prey biomass present in the stomachs of Notothenia angustifrons, $N$. gibberifrons, and $N$. larseni, and data on feeding periodicity, are combined with information already available on gastric evacuation rates (Crawford and McCleave, in press) to estimate daily rations.

Quantitative estimates of the importance of krill Euphausia superba as prey for coastal Antarctic fishes are also presented. Several species are known to consume krill (Permitin, 1970; Permitin and Tarverdiyeva, 
1972,1978 ) but previous data are generally not quantitative. The degree to which krill resources support Antarctic fishes is a subject of current interest (The Oceanic Society, 1980). Reduction of Antarctic whale populations and the resulting decrease in predation on krill, suggests a surplus of more than 150 million tons of krill (Laws, 1977) available for possible human exploitation. Little is known, however, about the quantitative importance of krill to members of the Antarctic food web.

\section{MATERIALS AND METHODS}

\section{Collection of Fishes}

Benthic fish communities were sampled at 5 locations in the Antarctic (Fig. 1 and Table 1) on 2 research expeditions aboard the $80 \mathrm{~m}$ research ship ARA 'Islas Orcadas' (formerly USNS 'Eltanin'). Several locations and depths were chosen so that communities having different fish species compositions, bottom types, and prey spectra could be examined. Fishes were collected primarily with a $3.0 \mathrm{~m}$ modified Blake trawl, although some collections were made using a $1.5 \mathrm{~m}$ modified Blake trawl.

Each community was sampled by trawling in the same area once during each $4 \mathrm{~h}$ interval of the day. At two community locations all collections could not be made during one $24 \mathrm{~h}$ period and it was necessary to trawl during 3 consecutive days to get samples from each $4 \mathrm{~h}$ interval. This sampling schedule provided a substantial size range of individuals from the common fish species, a sufficient number of each of the rarer species, and also data on feeding chronology within and among species. Samples were later analyzed for differences in both community structure and trophic ecology between trawling stations within a community. No such differences were found.

\section{Analysis of Trophic Ecology}

Fishes were identified and counted and, unless large numbers of specimens made measurement of each impractical, total lengths of all fishes were measured to

Fig. 1. Scotia Sea and adjacent area with locations of fish communities sampled. Antarctic

Convergence indicated by a dashed line

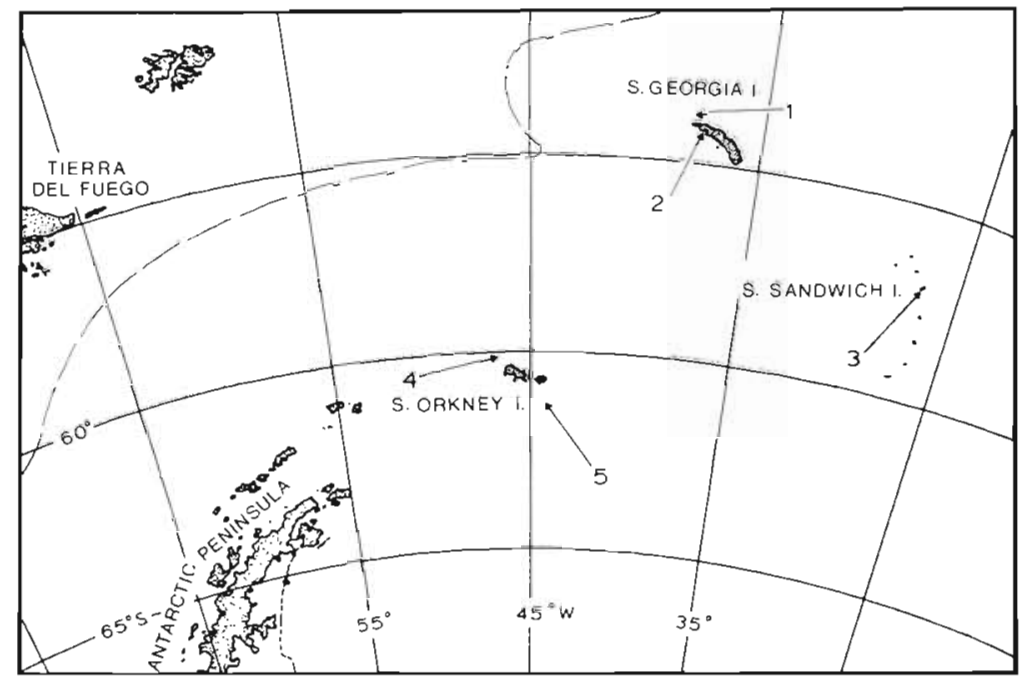

Table 1. Antarctic fish community physical data

\begin{tabular}{|c|c|c|c|c|c|c|}
\hline $\begin{array}{l}\text { Community } \\
\text { number }\end{array}$ & Location & Latitude & Longitude & $\begin{array}{l}\text { Depth } \\
\text { range } \\
\text { (m) }\end{array}$ & Dates & $\begin{array}{c}\text { Size of } \\
\text { Blake trawl } \\
\text { (m) }\end{array}$ \\
\hline 1 & S. Georgia Island, N. of western tip & $53^{\circ} 39.4^{\prime} \mathrm{S}$ & $37^{\circ} 59.6^{\prime} \mathrm{W}$ & $123-150$ & 12-14 May 1975 & 3.0 \\
\hline 2 & $\begin{array}{l}\text { S. Georgia Island, S.W. shore, entrance to } \\
\text { King Haakon Bay }\end{array}$ & $54^{\circ} 11.9^{\prime} \mathrm{S}$ & $37^{\circ} 38.9^{\prime} \mathrm{W}$ & $57-90$ & 9-10 June 1975 & $\begin{array}{l}1.5 \\
\text { and } 3.0\end{array}$ \\
\hline 3 & $\begin{array}{l}\text { S. Sandwich Islands, between Candlemas } \\
\text { and Vindication Islands }\end{array}$ & $57^{\circ} 6.4^{\prime} \mathrm{S}$ & $26^{\circ} 44,0^{\prime} \mathrm{W}$ & $15-70$ & 23-25 May 1975 & $\begin{array}{l}1.5 \\
\text { and } 3.0\end{array}$ \\
\hline 4 & S. Orkney Islands, N.W. of Coronation Island & $60^{\circ} 26.7^{\prime} \mathrm{S}$ & $46^{\circ} 25.0^{\prime} \mathrm{W}$ & 93-159 & 15-16 Feb. 1976 & 3.0 \\
\hline 5 & S. Orkney Islands, S. of Laurie Island & $61^{\circ} 18.3^{\prime} \mathrm{S}$ & $44^{\circ} 25.7^{\prime} \mathrm{W}$ & $274-305$ & 21-22 Feb. 1976 & 3.0 \\
\hline
\end{tabular}


the nearest mm. Invertebrates in the trawl samples were identified to major taxonomic group, and their relative biomasses estimated. The individuals in each fish species, or a size-range subsample of 30 specimens, were dissected and the stomach contents removed. Prey organisms were fixed in $10 \%$ formalin and transferred within 1 week to $70 \%$ ethanol. Fishes were fixed in $10 \%$ formalin. Prey organisms and a majority of the fishes were shipped back to the University of Maine.

In the laboratory, each fish (minus its stomach and contents) was weighed to the nearest $0.1 \mathrm{~g}$. The stomach contents of each fish was sorted separately into general taxonomic groups (e.g. gammaridean amphipod, isopod, errant and sedentary polychaetes). Prey in some groups were further identified to family or to species. The number of individuals in each prey category was recorded whenever possible. Small rocks and sediment, if present, were noted and discarded. Stage of digestion was recorded for amphipods and isopods, euphausiids and mysids, and for polychaetes, to contribute information on feeding chronology. Prey were dried at $60^{\circ} \mathrm{C}$, cooled in a desiccator, and weighed to the nearest $0.1 \mathrm{mg}$. The percentage composition of the diet by dry weight was calculated for each fish. Mean percentage composition of the diet and percentage frequency of occurrence of each prey category were then calculated for each fish species within a community. To illustrate changes in food habits accompanying growth, species for which a substantial size range was captured were divided into several size groups and diet composition calculations done separately for each.

Percentage composition of the diet by weight was used as the major means of describing a fish species' prey, because this method most accurately describes the importance of a prey category as an energy source. Percentage frequency of occurrence of each prey category provided additional information on those prey frequently consumed in small quantities.

The tubes of sedentary polychaetes and other tubedwelling prey, constructed of small rocks or finer sediment, were not included in the diet composition calculations. In some cases well-digested polychaetes, especially sedentary polychaetes, could not be separated from small rocks and sediment, and ashing was necessary to prevent an over-estimation of the importance of polychaetes. The polychaetes with associated rocks and sediment were ignited at $500^{\circ} \mathrm{C}$ for $4 \mathrm{~h}$ to oxidize the organic material. The weight of ash was subtracted from the original dry weight to yield ash free dry weight. This weight was corrected for the weight of natural ash in the polychaete tissue by multiplying the ash free dry weight by 1.25 (a mean of $20 \%$ ash was obtained for 50 polychaetes with no associated sediment or rocks).

Proportional overlap in prey consumed between all species pairs was calculated using the coefficient $C_{i h}$ $=1-1 / 2 \Sigma\left|P_{i j}-P_{h_{1}}\right|$, where $P_{i j}$ and $P_{h j}$ are the proportions of the diets of fish species $i$ and $h$, respectively, which are composed of prey $j$ (Colwell and Futuyma, 1971). This coefficient is 0 when no prey are shared and 1 when the diets of species $i$ and $h$ are the same.

Daily rations were calculated in terms of dry prey weight consumed $\mathrm{d}^{-1}$, expressed as percentages of wet, and dry, body weight. The following formula was used: $R_{T}=24 \overline{\mathrm{S}} \alpha$; where $\mathrm{R}_{T}$ is daily ration, $\overline{\mathrm{S}}$ is mean dry prey biomass in stomachs over a $24 \mathrm{~h}$ period expressed as either a proportion of wet or dry body weight, and $\alpha$ is gastric evacuation rate (Eggers, 1977). Dry body weight was calculated from wet using a mean value of $75.6 \%$ water in whole fish (from Vinogradov, 1953).

\section{Analysis of Community Structure}

The structure of each fish community was described on the basis of percentage composition of the community by number of individuals and by the total biomass of each species. Biomass calculations were done primarily by adding the weights of the specimens in each species. For those fish which were measured aboard the ship and then discarded, weights were calculated from the following length-weight equations, each determined from a size range of approximately 30 specimens:

Notothenia angustifrons

N. gibberifrons

N. larseni

N. nudifrons

$$
\begin{aligned}
& W=0.0085 \mathrm{~L}^{2.9995} ; r=0.98 \\
& W=0.0026 \mathrm{~L}^{3.3422} ; r=0.99 \\
& W=0.0052 \mathrm{~L}^{3.0817} ; r=0.99 \\
& W=0.0065 \mathrm{~L}^{3.1273} ; \mathrm{r}=0.99
\end{aligned}
$$

where $\mathrm{W}=$ weight in $\mathrm{g}$ and $\mathrm{L}=$ total length in $\mathrm{mm}$. In 12 trawl samples, a large number of Notothenia angustifrons, $N$. gibberifrons, $N$. larseni, or $N$. nudifrons (in 2, 2, 9 and 1 station[s]) made measurement and preservation of all specimens impractical and most were counted and discarded. It was necessary to estimate the lengths of such specimens from the length distribution of the same species from stations within the community where all individuals were measured. Analysis of size distributions for these species indicated no substantial differences among stations within a community. Biomasses were then calculated from estimated lengths.

Species diversity was calculated for each fish community using (1) Shannon-Wiener diversity index: $H^{\prime}$ $=-\Sigma P_{1} \ln P_{1}$ where $P_{1}$ is the proportion of individuals within the community which belong to species $i$ (Shan- 
non and Weaver, 1949) and (2) Evenness index: $e=H^{\prime}$ (ln $S)^{-1}$, where $H^{\prime}$ is the Shannon-Wiener diversity index and $S$ is the number of species in the community (Pielou, 1966).

\section{RESULTS}

\section{Community 1 - South Georgia Island}

Community 1 was located at $123-150 \mathrm{~m}$ depth, $35.5 \mathrm{~km}$ northwest of South Georgia Island (Fig. 1, Table 1). Sea surface temperature was $2.0^{\circ} \mathrm{C}$; bottom water temperature measurements were not available.

Ten species of fish were captured. Species diversity was low as nearly $90 \%$ of the individuals in the community were Notothenia larseni (Table 2). N. gibberi- frons and $N$. nudifrons together comprised most of the rest of the fishes. The $H^{\prime}$ and $e$ indices of fish species diversity were 0.481 and 0.209 , respectively. The dominant species in terms of biomass was also $N$. larseni, with $N$. gibberifrons being a substantial but less important species. Big individuals in the two large-bodied channichthyid species Chaenocephalus aceratus and Champsocephalus gunneri together comprised nearly $10 \%$ of the fish community biomass. Pseudochaenichthys georgianus, Muraenolepis microps, Parachaenichthys georgianus, Artedidraco mirus, and an unidentified liparid were minor components. The one liparid was not identified because of taxonomic uncertainty within Antarctic liparids.

Specimens from 9 fish species (all but the single liparid) contained food and were analyzed for prey

Table 2. Community 1 - South Georgia Island. Fish community structure and number of individuals in each species for which prey were examined

\begin{tabular}{|c|c|c|c|c|c|}
\hline Species & $\begin{array}{l}\text { Number } \\
\text { captured }\end{array}$ & $\begin{array}{c}\text { Percent } \\
\text { by number }\end{array}$ & $\begin{array}{l}\text { Weight } \\
\text { captured } \\
\text { (g) }\end{array}$ & $\begin{array}{l}\text { Percent } \\
\text { by weight }\end{array}$ & $\begin{array}{c}\text { Number in } \\
\text { which prey } \\
\text { were examined }\end{array}$ \\
\hline \multicolumn{6}{|l|}{ Nototheniidae: } \\
\hline Notothenia larseni & 3,588 & 88.7 & 82,506 & 70.3 & 162 \\
\hline Notothenia gibberifrons & 237 & 5.9 & 17,279 & 14.7 & 147 \\
\hline Notothenia nudifrons & 161 & 4.0 & 3,648 & 3.1 & 108 \\
\hline \multicolumn{6}{|l|}{ Harpagiferidae: } \\
\hline Artedidraco mirus & 23 & 0.6 & 186 & 0.2 & 17 \\
\hline \multicolumn{6}{|l|}{ Channichthyidae: } \\
\hline Chaenocephalus aceratus & 12 & 0.3 & 5,615 & 4.8 & 3 \\
\hline Champsocephalus gunneri & 12 & 0.3 & 5,538 & 4.7 & 9 \\
\hline Pseudochaenichthys georgianus & 2 & $<0.1$ & 1,283 & 1.1 & 1 \\
\hline \multicolumn{6}{|l|}{ Muraenolepidae: } \\
\hline Muraenolepis microps & 6 & 0.1 & 735 & 0.6 & 5 \\
\hline \multicolumn{6}{|l|}{ Bathydraconidae: } \\
\hline Parachaenichthys georgianus & 5 & 0.1 & 503 & 0.4 & 4 \\
\hline Liparidae (unidentified) & 1 & $<0.1$ & 7 & $<0.1$ & 0 \\
\hline Total & 4,047 & & 117,300 & & 456 \\
\hline
\end{tabular}

Table 3. Community 1 - South Georgia Island. Proportional prey overlap $\left(C_{i h}\right)$ between fish species

\begin{tabular}{|c|c|c|c|c|c|c|c|c|}
\hline & $\begin{array}{c}N . \\
\text { gibber. }\end{array}$ & $\begin{array}{c}N . \\
\text { nudifrons }\end{array}$ & $\begin{array}{c}\text { A. } \\
\text { mirus }\end{array}$ & $\begin{array}{l}\text { Chaeno. } \\
\text { aceratus }\end{array}$ & $\begin{array}{c}\text { Champso. } \\
\text { gunneri }\end{array}$ & $\begin{array}{c}\text { Pseudo } \\
\text { georg. }\end{array}$ & $\begin{array}{c}M \\
\text { microps }\end{array}$ & $\begin{array}{l}\text { Para. } \\
\text { georg. }\end{array}$ \\
\hline Notothenia larseni & .096 & .110 & .114 & .032 & .838 & .786 & .147 & .056 \\
\hline Notothenia gibberifrons & & .643 & .494 & .004 & .124 & .053 & .134 & .078 \\
\hline Notothenia nudifrons & & & .480 & .010 & .138 & .050 & .257 & 152 \\
\hline Artedidraco mirus & & & & .029 & .093 & .028 & .296 & .085 \\
\hline Chaenocephalus aceratus & & & & & .005 & .042 & .284 & .562 \\
\hline Champsocephalus gunneri & & & & & & .662 & .092 & .019 \\
\hline Pseudochaenichthys georgianus & & & & & & & .050 & .042 \\
\hline Muraenolepis microps & & & & & & & & .550 \\
\hline
\end{tabular}




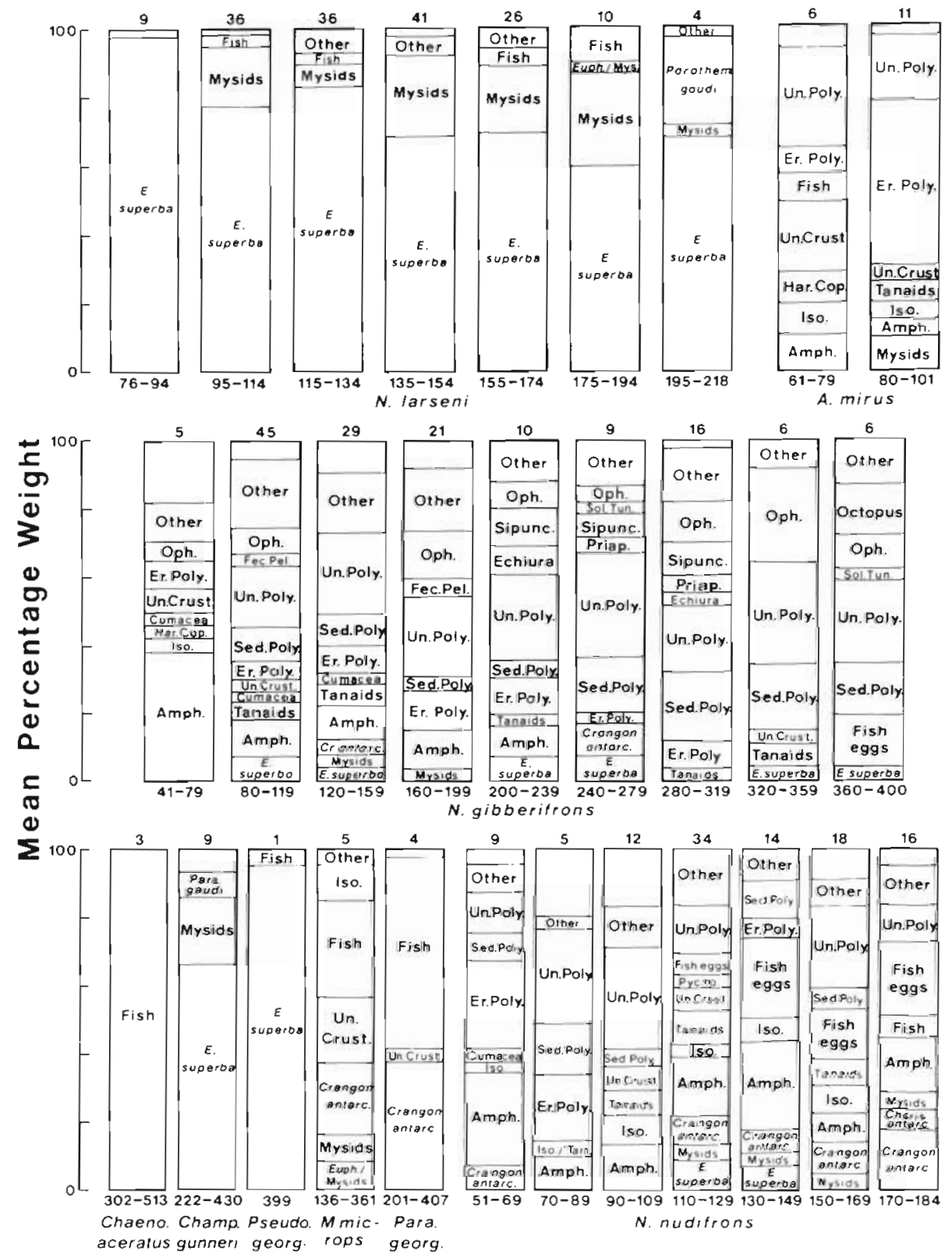

Fig. 2. Community 1 - South Georgia Island. Prey consumed by species in the fish community. Numbers below each histogram are fish total lengths (mm); those above each histogram, number of fish in which prey were examined. Unlabeled sections at the top of histograms represent unidentified prey. Prey abbreviations: Amph.: gammaridean amphipods; Choris antarc.: Chorismus antarcticus; Crangon antarc. and $C_{r}$. antarc: Crangon antarcticus; Er. Poly.: errant polychaetes; E. superba: Euphausia superba; Euph./Mys.: Euphausia/mysids; Fec. Pel.: fecal pellets; Har. Cop.: harpacticoid copepods; Iso.: isopods; Iso./Tan.: isopods/tanaids; Oph.: ophiuroids Parathem. gaudi. and Para. gaudi: Parathemisto gaudichaudii; Priap.: priapulids; Pycno. pycnogonids; Sed. Poly.: sedentary polychaetes; Sipunc.: sipunculids; Sol. Tun.: solitary tunicates; Un. Crust.: unidentified crustacea; Un. Poly.: unidentified polychaetes
(Fig. 2). Notothenia larseni preyed primarily on krill Euphausia superba. In larger fish, mysids (primarily Antarctomysis maxima) and the hyperiid amphipod Parathemisto gaudichaudii increased in importance.

Small (41-79 mm) Notothenia gibberifrons preyed primarily on small crustaceans. With increasing body size polychaetes, sipunculids, priapulids, echiurans, and ophiuroids became more important prey groups. The fecal pellets consumed by fish in some size groups likely came from digestion of one or more of the worm groups. Data from those polychaetes that could be identified suggest that sedentary polychaetes were more important than errant, especially for large fish.
The $15 \%$ of the diet of $360-400 \mathrm{~mm}$ fish composed of octopus was due to the consumption of a large, $5.2 \mathrm{~g}$ dry weight, Graneledone (likely G. challengeri) by one fish.

Notothenia nudifrons preyed heavily on polychaetes, especially errant polychaetes, and on gammaridean amphipods and isopods. The caridean shrimp Crangon antarcticus and Chorismus antarcticus, fish eggs, and mysids increased in importance as prey with increasing fish size.

Artedidraco mirus preyed primarily on errant polychaetes and various crustacean groups. Larger fish fed more on polychaetes and less on crustaceans. 
Insufficient numbers of the other 5 fish species were captured to allow analysis of changes in food habits accompanying growth (Fig. 2).

Members of this fish community clearly partitioned the prey resources. Proportional prey overlap calculations show that although most items were identified only to major prey category, overlap was low, generally much less than 0.500 (Table 3 ). Thus, in most cases substantially less than half the prey, by weight of general prey categories, was shared by any two fish species.

A majority of the community prey resource partitioning, that by the most abundant species Notothenia larseni, $N$. gibberifrons, and $N$. nudifrons, was due to morphological and behavioral adaptations for feeding in different habitat zones within the community. $N$. larseni had the most pronounced pelagic feeding habits. This species has a fusiform body and a terminal mouth; it preyed above the bottom on Euphausia superba, and to a lesser extent on mysids. N. gibberifrons has a subterminal mouth and is more dorsoventrally compressed, especially anteriorly, than is $N$. larseni. Medium and large fish fed on benthos, especially on infauna (sedentary polychaetes, sipunculids, priapulids, and echiurans). Although smaller N. gibberifrons preyed less on these groups and more on crustaceans, they were also closely associated with the bottom sediments in their feeding habits. Harpacticoid copepods and cumaceans (both benthic and the latter infaunal) were taken, respectively, by 56 and $49 \%$ of the fish $<200 \mathrm{~mm}$ total length. Also, detritus and the pebble and sediment constructed tubes of infaunal organisms constituted $9 \%$ by weight of the stomach contents of fish $<120 \mathrm{~mm}$ long. Rocks and sediment were present in $93 \%$ of all stomachs. $N$. nudifrons has a terminal mouth and a fusiform body but unlike $N$. larseni preyed to only a minor extent on E. superba and mysids. $N$. nudifrons was primarily a benthos feeder, but unlike $N$. gibberifrons preyed more on epifauna (errant polychaetes, amphipods, isopods, shrimp, fish eggs) than on infauna. Harpacticoid copepods and cumaceans had only 7 and $5 \%$ frequencies of occurrence, respectively; and detritus and the pebble and sediment tubes of infaunal organisms constituted only $0.7 \%$ of $N$. nudifrons stomach contents, values approximately one tenth those for $N$. gibberifrons. Rocks and sediment were present in $63 \%$ of the $N$. nudifrons, compared to $93 \%$ of $N$. gibberifrons. These facts indicate a more epifaunal feeding biology (taking prey either on the bottom, associated with sponges, bryozoans, etc., or active near the bottom) in $N$. nudifrons than in $N$. gibberifrons.

The different feeding modes of these two species suggest that the gammaridean amphipod and isopod prey of Notothenia gibberifrons may have different habits and belong to different taxonomic groups than that taken by $N$. nudifrons. Additional evidence for this is the frequency of occurrence of isopods in the families Anthuridae (generally infaunal) and Arcturidae (generally epifaunal on sediments, sponges, or bryozoans). No arcturid isopods were found in $N$. gibberifrons and anthurids had a $20 \%$ frequency of occurrence. No anthurids were found in $N$. nudifrons and arcturids had a $3 \%$ frequency of occurrence. Thus, overlap in gammaridean amphipod and isopod prey at the species level of identification may be less than is indicated by overlap calculations based on general 'amphipod' and 'isopod' categories, increasing the actual partitioning of food resources by these two species.

The more minor species in the fish community also appear, based on limited sample sizes, to effectively partition the prey resources. The only cases where prey overlap was very high were species pairs in which Euphausia superba, and to a lesser extent mysids, were important prey for both species. The channichthyids Champsocephalus gunneri and Pseudochaenichthys georgianus overlapped greatly with each other and with Notothenia larseni, mainly because of the importance of E. superba and mysids. E. superba is an extremely abundant prey resource in the Antarctic, likely minimizing competition for these prey. This is particularly true in austral summer and fall after the krill concentrations respond to increased primary production during the summer phytoplankton blooms. The same may be true, on a local scale, for phytoplanktivorous mysids, also minimizing potential competition for these prey. Moderate prey overlap values were found between Parachaenichthys georgianus and Chaenocephalus aceratus and between $P$. georgianus and Muraenolepis microps indicating some sharing of fish and Crangon antarcticus prey by these three species.

Euphausia superba and mysids (in particular Antarctomysis maxima) were the major prey resources supporting this fish community, primarily because of their importance to the dominant Notothenia larseni and two of the channichthyids. Benthic infauna and epifauna was major prey for less than $20 \%$ of the fish community biomass.

Notothenia larseni, N. gibberifrons, and N. nudifrons were captured in sufficient abundance in each of the 6 trawl samples (one taken during each $4 \mathrm{~h}$ interval of the day) to allow an examination for possible feeding chronology. No diel patterns were found in either stage of prey digestion or prey biomass in stomachs for any species. $N$. larseni, $N$. gibberifrons and $N$. nudifrons had mean dry prey biomass values ( \pm two standard errors of the mean) of $0.421 \pm 0.054 \%$ wet and $1.725 \pm$ $0.221 \%$ dry body weight, $0.196 \pm 0.037 \%$ wet and 
Table 4. Community 2 - South Georgia Island. Fish community structure and number of individuals in each species for which prey were examined

\begin{tabular}{|c|c|c|c|c|c|}
\hline Species & $\begin{array}{l}\text { Number } \\
\text { captured }\end{array}$ & $\begin{array}{c}\text { Percent } \\
\text { by number }\end{array}$ & $\begin{array}{l}\text { Weight } \\
\text { captured } \\
\text { (g) }\end{array}$ & $\begin{array}{c}\text { Percent } \\
\text { by weight }\end{array}$ & $\begin{array}{c}\text { Number in } \\
\text { which prey } \\
\text { were examined }\end{array}$ \\
\hline \multicolumn{6}{|l|}{ Nototheniidae: } \\
\hline Notothenia angustifrons & 263 & 52.6 & 3,629 & 35.1 & 97 \\
\hline Notothenja nudifrons & 146 & 29.2 & 1,622 & 15.7 & 77 \\
\hline Notothenia gibberifrons & 52 & 10.4 & 298 & 2.9 & 50 \\
\hline Trematomus hansoni & 3 & 0.6 & 166 & 1.6 & 3 \\
\hline Notothenia Iarseni & 2 & 0.4 & 38 & 0.4 & 2 \\
\hline Notothenia rossii & 1 & 0.2 & 526 & 5.1 & 1 \\
\hline \multicolumn{6}{|l|}{ Channichthyidae: } \\
\hline Champsocephalus gunneri & 10 & 2.0 & 887 & 8.6 & 8 \\
\hline Champsocephalus esox & 3 & 0.6 & 373 & 3.6 & 1 \\
\hline \multicolumn{6}{|l|}{ Muraenolepidae: } \\
\hline Muraenolepis microps & 7 & 1.4 & 425 & 4.1 & 3 \\
\hline \multicolumn{6}{|l|}{ Harpagiferidae: } \\
\hline Artedidraco mirus & 6 & 1.2 & 38 & 0.4 & 1 \\
\hline Harpagifer bispinis & 1 & 0.2 & 5 & $<0.1$ & 0 \\
\hline \multicolumn{6}{|l|}{ Bathydraconidae: } \\
\hline Parachaenichthys georgianus & 4 & 0.8 & 2,317 & 22.4 & 4 \\
\hline Psilodraco breviceps & 2 & 0.4 & 17 & 0.2 & 0 \\
\hline Total & 500 & & 10,341 & & 247 \\
\hline
\end{tabular}

$0.803 \pm 0.152 \%$ dry body weight, and $0.223 \pm$ $0.057 \%$ wet and $0.914 \pm 0.234 \%$ dry body weight, respectively, in the 6 trawl samples combined.

\section{Community 2 - South Georgia Island}

Community 2 was located at $57-90 \mathrm{~m}$ depth at the mouth of King Haakon Bay, South Georgia Island, $4.4 \mathrm{~km}$ from the south shore (Fig, 1, Table 1). Sea surface temperature was $1.4^{\circ} \mathrm{C}$.

Thirteen species of fish were captured (Table 4). Notothenia angustifrons, $N$. nudifrons, and $N$. gibberifrons represented $92 \%$ of the individuals in the community. The $H^{\prime}$ and $e$ indices of fish species diversity were 1.293 and 0.504 , respectively. $N$. angustifrons and $N$. nudifrons also dominated in terms of biomass. Big individuals in several species which attain large sizes were also important in terms of biomass. Parachaenichthys georgianus comprised $22 \%$ of the biomass, and with Champsocephalus gunneri and $C$. esox, N. rossii, and Muraenolepis microps, represented $44 \%$ of the fish by weight. Trematomus hansoni, $N$. larseni, Psilodraco breviceps, Artedidraco mirus, and Harpagifer bispinis were minor components,

Specimens from 11 fish species contained prey and were analyzed for food habits (Fig. 3); the one Нarpagifer bispinis and two Psilodraco breviceps did not contain prey. Notothenia angustifrons and $N$. nudif-

Table 5. Community 2 - South Georgia Island. Proportional prey overlap $\left(C_{i h}\right)$ between fish species

\begin{tabular}{|c|c|c|c|c|c|c|c|c|c|c|}
\hline & $\begin{array}{l}\text { N. nudif- } \\
\text { rons }\end{array}$ & $\begin{array}{c}N \\
\text { gibber. }\end{array}$ & $\begin{array}{c}N . \\
\text { larseni }\end{array}$ & $\underset{\text { rossii }}{N .}$ & $\begin{array}{c}T \\
\text { hansoni }\end{array}$ & $\begin{array}{c}\text { Champso. } \\
\text { gunneri }\end{array}$ & $\begin{array}{c}\text { Champso. } \\
\text { esox }\end{array}$ & $\begin{array}{c}M . \\
\text { microps }\end{array}$ & $\begin{array}{c}\text { A. } \\
\text { mirus }\end{array}$ & $\begin{array}{l}\text { Para. } \\
\text { georg. }\end{array}$ \\
\hline Notothenia angustifrons & .627 & .703 & .409 & .294 & .444 & .558 & .408 & .252 & .227 & .164 \\
\hline Notothenia nudifrons & & .669 & .424 & .400 & .273 & .462 & .288 & .318 & .153 & .341 \\
\hline Notothenia gibberifrons & & & .334 & .262 & .326 & .404 & .261 & .174 & .233 & .085 \\
\hline Notothenia larseni & & & & .762 & .290 & .478 & .300 & .398 & .000 & .331 \\
\hline Notothenia rossii & & & & & .182 & 371 & .186 & .483 & .100 & .412 \\
\hline Trematomus hansoni & & & & & & 810 & .795 & .001 & .200 & .003 \\
\hline Champsocephalus gunneri & & & & & & & .688 & .188 & .128 & .190 \\
\hline Champsocephalus esox & & & & & & & & .096 & .000 & .099 \\
\hline Muraenolepis microps & & & & & & & & & .088 & .624 \\
\hline Artedidraco mirus & & & & & & & & & & .001 \\
\hline
\end{tabular}



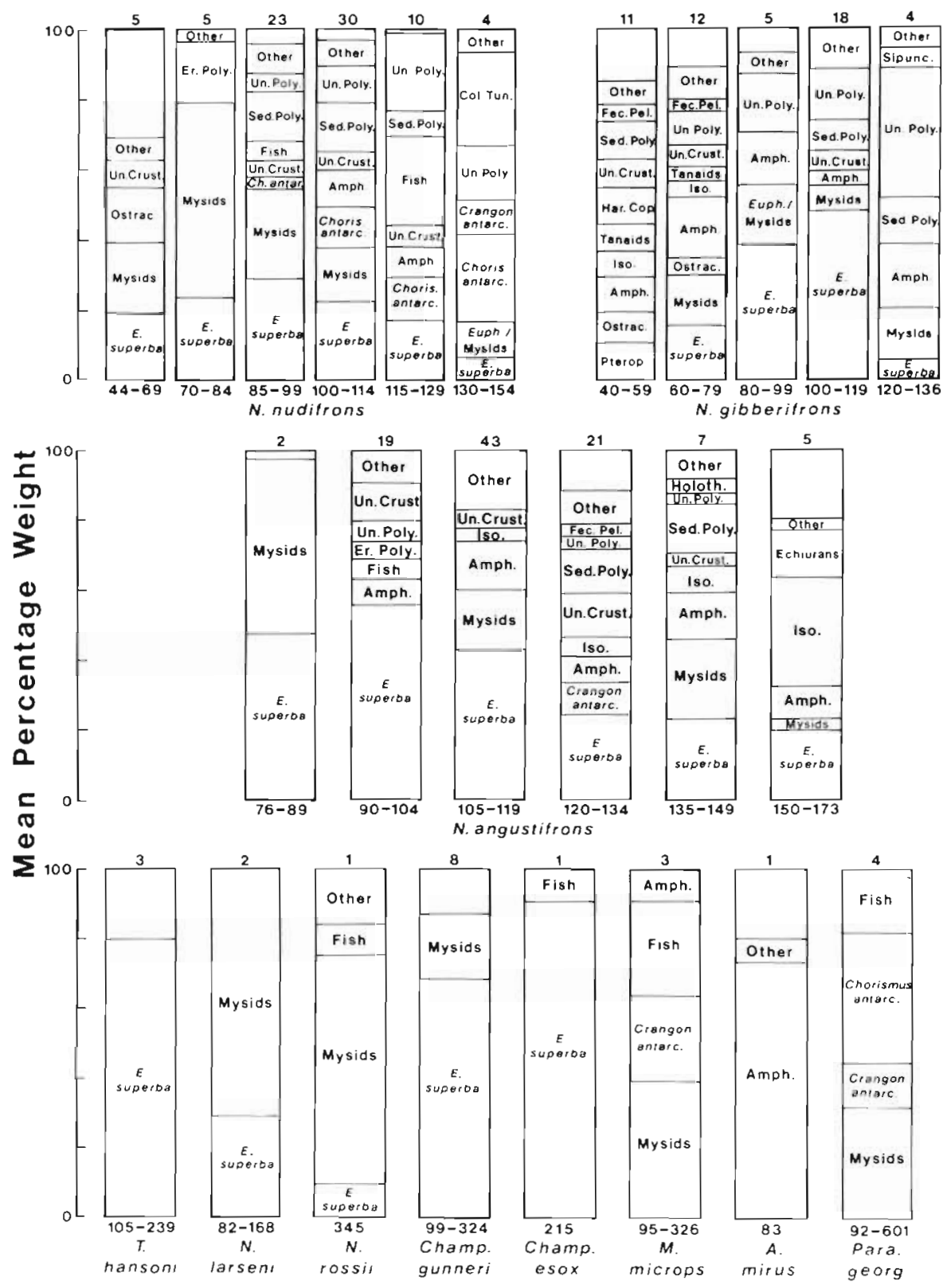

Fig. 3. Community 2 - South Georgia Island. Prey consumed by species in the fish community. Numbers below each histogram are fish total lengths $(\mathrm{mm})$; those above each histogram, number of fish in which prey were examined. Unlabeled sections at the top of histograms represent unidentified prey. Prey abbreviations as in Figure 2 and as follows: Ch. antar.: Chorismus antarcticus; Col. Tun.: colonial tunicates; Holoth.: holothurians; Ostrac.: ostracods; Pterop.: pteropods rons, especially in smaller size groups, both preyed heavily on Euphausia superba and mysids (primarily Artarctomysis maxima). With increasing body size, both species preyed more on benthic prey groups. Gammaridean amphipods, isopods, and sedentary polychaetes were taken by $N$. angustifrons; and shrimp (Chorismus antarcticus and Crangon antarcticus) and polychaetes, especially sedentary polychaetes, were taken by $N$. nudifrons. $N$. gibberifrons between 40 and $59 \mathrm{~mm}$ long fed on pteropods, several groups of small crustaceans, and sedentary polychaetes. Larger fish preyed more on the larger crustaceans E. superba and mysids (primarily A. maxima). Gammaridean amphipods and sedentary polychaetes were also important prey for larger $N$. gibberifrons. The other 8 species were captured in small numbers and changes in food habits accompanying growth could not be analyzed (Fig. 3).

The dominant species in the community, Notothenia angustifrons, $N$. nudifrons, and $N$. gibberifrons, had comparatively high levels of prey overlap (Table 5). A large portion of this overlap was due to Euphausia superba and to a lesser extent Artarctomysis maxima, prey constituting $>30-40 \%$ of the prey biomass of most size groups in all 3 species. Some partitioning of non-E. superba and A. maxima prey is evident. Medium and large $N$. nudifrons fed substantially on the epifaunal shrimp Chorismus antarcticus and Cran- 
gon antarcticus, prey of minor importance to $N$. gibberifrons or $N$. angustifrons (which has a body form similar to $N$ gibberifrons, but with a terminal mouth). Isopods were important prey only for medium and large $N$, angustifrons, and gammaridean amphipods were important only for $N$. angustifrons and $N$. gibberifrons. Rocks and sediment were present in $29 \%$ of the $N$. nudifrons compared to $82 \%$ and $71 \%$ of the $N$. gibberifrons and $N$. angustifrons, respectively, suggesting that $N$. nudifrons depended less on infauna than did the other two species.

Thus, although some food resource partitioning is evident among Notothenia angustifrons, $N$. nudifrons, and $N$. gibberifrons, there was a high degree of overlap due largely to predation by all 3 species on an abundant Euphausia superba and Artarctomysis maxima resource. Predation on these abundant prey may have effectively reduced potential competition and allowed more overlap in other prey groups, especially between $N$. angustifrons and $N$. gibberifrons.

Sample sizes of the other species in the fish community were low, but many species pairs appeared to have low proportional prey overlap values. In nearly all cases of moderate to high overlap, the shared prey resources were Euphausia superba and Artarctomysis maxima. The only exception is an overlap value of 0.624 between Parachaenichthys georgianus (an important species in terms of biomass) and Muraenolepis microps. Some of the overlap was due to $A$. maxima, but both took fish and Crangon antarcticus.

Krill (Euphausia superba) and mysids (particularly Artarctomysis maxima) were the major prey resource supporting the biomass of fishes in this community. Virtually all species consumed substantial amounts of one or both prey items. Several benthic infauna and epifauna prey groups, including sedentary polychaetes, gammaridean amphipods, and isopods were less important than krill and mysids. The shrimp Chorismus antarcticus and Crangon antarcticus were important because of their contribution to the diets of Parachaenichthys georgianus, Notothenia nudifrons, and M. microps.

Notothenia angustifrons, $N$. nudifrons, and $N$. gibberifrons were analyzed for feeding chronology. No diel patterns of feeding were found in either stage of prey digestion or mean prey biomass in the stomachs. $N$. angustifrons, $N$. nudifrons, and $N$. gibberifrons had mean dry prey weight values ( \pm 2 standard errors of the mean) of $0.352 \pm 0.233 \%$ wet and $1.442 \pm 0.955 \%$ dry body weight, $0.404 \pm 0.092 \%$ wet and $1.656 \pm$ $0.377 \%$ dry body weight, and $0.383 \pm 0.102 \%$ wet and $1.570 \pm 0.418 \%$ dry body weight, respectively, in the 6 trawl samples combined.

\section{Community 3 - South Sandwich Islands}

Community 3 was located at 15-70 m depth, $3.5 \mathrm{~km}$ east of Vindication Island (approximately midway between Candlemas and Vindication Islands). South Sandwich Islands (Fig. 1, Table 1). Sea surface temperature was $-1.0^{\circ} \mathrm{C}$. All the South Sandwich Islands are volcanic in origin. Candlemas I. has a currently active volcanic vent and bottom sediments consisting of small volcanic rocks and cinders with little finer organic sediment. This bottom type was unlike that at either South Georgia Island or the South Orkney Islands, and there was no well established epifaunal or infaunal invertebrate community at this location.

Five species of fish were captured (Table 6). Species diversity was very low as $96 \%$ of the specimens were Notothenia angustifrons $\left(H^{\prime}=0.194 ; e=0.121\right)$. Harpagifer bispinis constituted $3 \%$ of the individuals and $N$. coriceps, $N$. rossii, and $N$. larseni together represented $1 \%$. $N$. angustifrons was also the dominant species in terms of biomass.

The major prey of all fishes, except for the single specimen of Notothenia larseni, was gammaridean

Table 6. Community 3 - South Sandwich Islands. Fish community structure and number of individuals in each species for which prey were examined

\begin{tabular}{|c|c|c|c|c|c|}
\hline Species & $\begin{array}{l}\text { Number } \\
\text { captured }\end{array}$ & $\begin{array}{c}\text { Percent } \\
\text { by number }\end{array}$ & $\begin{array}{l}\text { Weight } \\
\text { captured } \\
\text { (g) }\end{array}$ & $\begin{array}{c}\text { Percent } \\
\text { by weight }\end{array}$ & $\begin{array}{c}\text { Number in } \\
\text { which prey } \\
\text { were examined }\end{array}$ \\
\hline \multicolumn{6}{|l|}{ Nototheniidae: } \\
\hline Notothenia angustifrons & 882 & 96.2 & 10,663 & 97.4 & 117 \\
\hline Notothenia coriiceps & 8 & 0.9 & 173 & 1.6 & 7 \\
\hline Notothenia rossii & 2 & 0.2 & 7 & 0.1 & 2 \\
\hline Notothenia larseni & 1. & 0.1 & 12 & 0.1 & 1 \\
\hline \multicolumn{6}{|l|}{ Harpagiferidae: } \\
\hline Harpagifer bispinis & 24 & 2.6 & 93 & 0.8 & 23 \\
\hline Total & 917 & & 10,948 & & 150 \\
\hline
\end{tabular}


amphipods (Fig. 4). Thus, the members of this fish community, with the possible exception of $N$. larseni, overlapped greatly in prey utilization at the level of general taxonomic group (Table 7).

The stomachs from 92 specimens, including representatives of all 5 fish species, contained amphipods in a condition sufficient for more specific identification. Amphipods from 32 Notothenia angustifrons, 8 Harpagifer bispinis, $4 \mathrm{~N}$. coriiceps, $1 \mathrm{~N}$. rossii and $1 \mathrm{~N}$. respectively; and Cardenio paurodactylus represented $10 \%, 28 \%$, and $10 \%$ of this biomass in $N$. angustifrons, $H$. bispinis and $N$. coriceps, respectively. Three other amphipod species, Jassa falcata, Orchomene rossi and Paraphoxus rotundifrons, were of minor importance. Rocks were present in $91 \%$ of the $N$. angustifrons and $78 \%$ of the $H$. bispinis stomachs, suggesting that amphipods were taken on the bottom by both species. Although there is some evidence that $N$. rossii and $N$. larseni took different amphipod

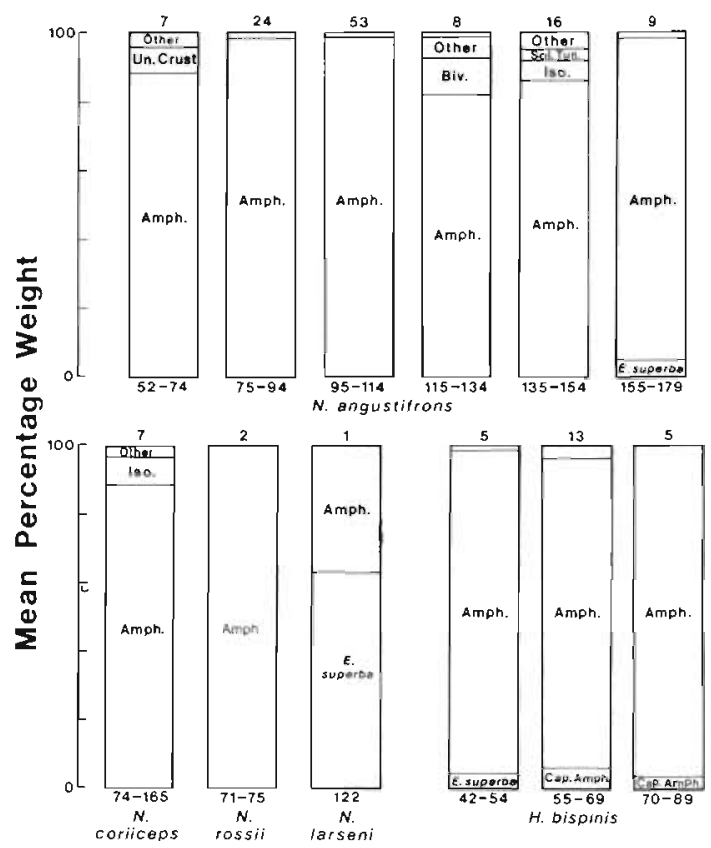

Fig. 4. Community 3 - South Sandwich Islands. Prey consumed by species in the fish community. Numbers below each histogram are fish total lengths ( $\mathrm{mm}$ ); those above each histogram, number of fish in which prey were examined. Unlabeled sections at the top of histograms represent unidentified prey. Prey abbreviations are as in Figure 2 and as follows: Biv.: bivalves; Cap. Amph.: caprellid amphipods

Table 7. Community 3 - South Sandwich Islands. Proportional prey overlap $\left(C_{i h}\right)$ between fish species

\begin{tabular}{lcccc|}
\hline & N. coriiceps & N. rossii & N. larseni & Harpagifer bispinis \\
\hline Notothenia angustifrons & .907 & .947 & .372 & .934 \\
Notothenia coriiceps & & .885 & .368 & .898 \\
Notothenia rossii & & & .368 & .924 \\
Notothenia larseni & & & .376 \\
\hline
\end{tabular}

larseni were identified, in most cases to species. A very low diversity of gammaridean amphipod prey was apparent from these identifications. Only 3 species of amphipods were important prey. The mean percentage weight of amphipods identifiable to species was approximately $10 \%$ of total prey biomass in $N$. angustifrons, $H$. bispinis, and $N$. coriiceps, $7 \%$ in $N$. rossii, and $21 \%$ in N. larseni. Gondogenia antarctica constituted $47 \%, 33 \%, 85 \%$, and $100 \%$ of identifiable amphipod biomass in $N$. angustifrons, $H$. bispinis, $N$. coriiceps and $N$. rossi, respectively; Pontogeniella longicornis represented $41 \%, 34 \%$, and $100 \%$ of this biomass in $N$. angustifrons, $H$. bispinis and $N$. larseni, species, sample sizes were too small to draw conclusions and it appears in most cases there was a high degree of prey overlap, at the species level of identification. This indicates the potential for severe competition by fishes in this community, possibly exclusive of $N$. larseni, and is likely a contributing factor to the very low fish species diversity.

Notothenia angustifrons showed no diel pattern in either stage of prey digestion of mean prey biomass in the stomachs. Mean dry prey weight ( \pm two standard errors of the mean) was $0.381 \pm 0.053 \%$ wet and 1.561 $\pm 0.217 \%$ dry body weight in the six trawl samples combined. 


\section{Community 4 - South Orkney Islands}

Community 4 was located at $93-159 \mathrm{~m}$ depth, $25.0 \mathrm{~km}$ from Coronation Island, South Orkney Islands (Fig. 1, Table 1). Sea surface temperature was $0.9^{\circ} \mathrm{C}$.

Eight species of fish were captured. Notothenia gibberifrons was the dominant species, and with $N$. larseni and $N$. nudifrons represented $96 \%$ of the individuals (Table 8). The $H^{t}$ and $e$ indices of fish species diversity were 1.159 and 0.557 , respectively. $N$. gibberifrons also dominated the biomass, with $N$. larseni, $N$. nudifrons, and Trematomus newnesi being less important. Large individuals of Chaenocephalus aceratus, Champsocephalus gunneri, and Parachaenichthys charcoti together comprised $16 \%$ of the biomass. T. eulepidotus was a minor component.

Specimens from all 8 fish species contained food and were analyzed for prey (Fig. 5). Notothenia gibberifrons in all size groups preyed heavily on sedentary polychaetes. Smaller individuals also consumed gammaridean amphipods, isopods, and cumaceans; and larger individuals preyed on benthic colonial tunicates and the hyperiid amphipod Parathemisto gaudichaudii.
Notothenia larseni in smaller size groups consumed primarily calanoid copepods and Euphausia superba. With increasing body size $N$. larseni fed less on the smaller (2-5 mm long) calanoid copepods and more on Iarger (25-40 mm long) E. superba.

Notothenia nudifrons preyed heavily on gammaridean amphipods, isopods, and polychaetes (particularly sedentary polychaetes). Cumaceans were taken by individuals in the smallest size group, and gastropods by fish in medium and large size groups.

Trematomus newnesi preyed on calanoid copepods, krill, and Parathemisto gaudichaudii. With increasing body size $T$. newnesi preyed more on krill and less on the other groups.

Insufficient numbers of the other four species were captured to permit analysis of changes in food habits accompanying growth (Fig. 5).

Members of the fish community clearly partitioned the prey resources. Proportional prey overlap values show that although most prey items were identified only to general taxonomic group, prey overlap was low, usually much less than 0.500 (Table 9).

Notothenia gibberifrons, $N$. larseni, and $N$. nudifrons, the most abundant species in the community,

Table 8. Community 4 - South Orkney Islands. Fish community structure and number of individuals in each species for which prey were examined

\begin{tabular}{|c|c|c|c|c|c|}
\hline Species & $\begin{array}{l}\text { Number } \\
\text { captured }\end{array}$ & $\begin{array}{c}\text { Percent } \\
\text { by number }\end{array}$ & $\begin{array}{c}\text { Weight } \\
\text { captured } \\
(g)\end{array}$ & $\begin{array}{c}\text { Percent } \\
\text { by weight }\end{array}$ & $\begin{array}{c}\text { Number in } \\
\text { which prey } \\
\text { were examined }\end{array}$ \\
\hline \multicolumn{6}{|l|}{ Nototheniidae: } \\
\hline Notothenia gibberifrons & 465 & 48.0 & 26,256 & 63.5 & 169 \\
\hline Notothenia larseni & 328 & 33.8 & 6,693 & 16.2 & 124 \\
\hline Notothenia nuditrons & 137 & 14.1 & 1,782 & 4.3 & 93 \\
\hline Trematomus newnesi & 29 & 3.0 & 1,224 & 3.0 & 26 \\
\hline Trematomus eulepidotus & 3 & 0.3 & 74 & 0.2 & 3 \\
\hline \multicolumn{6}{|l|}{ Channichthyidae: } \\
\hline Chaenocephalus aceratus & 4 & 0.4 & 3,093 & 7.5 & 3 \\
\hline Champsocephalus gunner & 2 & 0.2 & 1,352 & 3.3 & 1 \\
\hline \multicolumn{6}{|l|}{ Bathydraconidae: } \\
\hline Parachaenichthys charcoti & 1 & 0.1 & 862 & 2.1 & 1 \\
\hline Total & 969 & & 41,336 & & 420 \\
\hline
\end{tabular}

Table 9. Community 4 - South Orkney Islands. Proportional prey overlap $\left(C_{h}\right)$ between fish species

\begin{tabular}{|c|c|c|c|c|c|c|c|}
\hline & $\begin{array}{c}N . \\
\text { larseni }\end{array}$ & $\begin{array}{c}N . \\
\text { nudifrons }\end{array}$ & $\begin{array}{c}T \\
\text { newnesi }\end{array}$ & $\begin{array}{c}T \\
\text { eulepidotus }\end{array}$ & $\begin{array}{l}\text { Chaeno. } \\
\text { aceratus }\end{array}$ & $\begin{array}{l}\text { Champso. } \\
\text { gunneri }\end{array}$ & $\begin{array}{c}\text { Para. } \\
\text { charcoti }\end{array}$ \\
\hline Notothenia gibberifrons & .260 & .552 & .132 & .096 & .033 & .020 & .004 \\
\hline Notothenia larseni & & .218 & 720 & .489 & .442 & .412 & .007 \\
\hline Notothenia nudifrons & & & 107 & .094 & .022 & .008 & .000 \\
\hline Trematomus newnesi & & & & .370 & 492 & .491 & .001 \\
\hline Trematomus eulepidotus & & & & & 114 & 115 & .000 \\
\hline Chaenocephalus aceratus & & & & & & .666 & .128 \\
\hline Champsocephalus gunneri & & & & & & & .000 \\
\hline
\end{tabular}



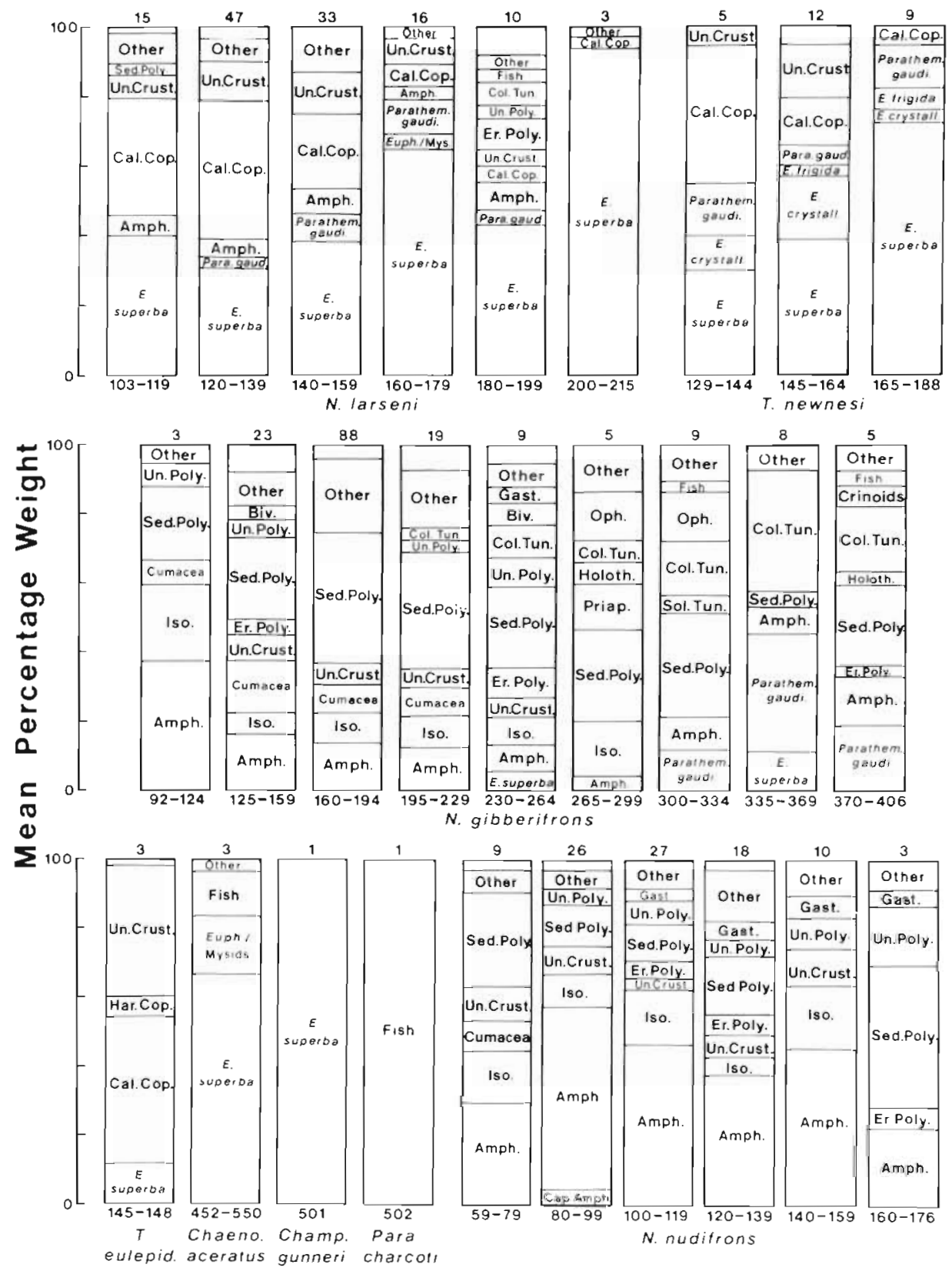

$229 \quad 230-264 \quad 265-299 \quad 300-334 \quad 335-369 \quad 370-406$ N. gibberitrons

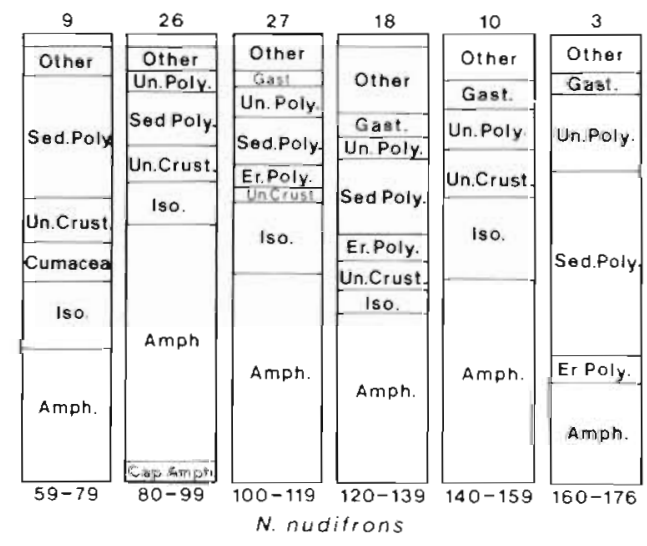

Fig. 5. Community 4-South Orkney Islands. Prey consumed by species in the fish community. Numbers below each histogram are fish total lengths $(\mathrm{mm})$; those above each histogram, number of fish in which prey were examined. Unlabeled sections at the top of histograms represent unidentified prey. Prey abbreviations are as in Figures 2, 3, and 4 and as follows: Cal. cop.: calanoid copepods; E. crystall.: Euphausia crystallarophias; E. frigida: Euphausia frigida; Gast.: gastropods

partitioned the prey to a large extent by morphological and behavioral adaptations for feeding in different habitat zones within the community. $N$. larseni had a more pelagic feeding mode, preying primarily on Euphausia superba and calanoid copepods. N. gibberifrons preyed primarily on benthos, to a large extent infauna. In addition to prey, there was a large amount of sedentary polychaete tubes and the pebble and sediment tubes of other tube-inhabiting infauna in the diet of $N$. gibberifrons. These tubes constituted $33 \%$ of the stomach contents by weight. The hyperiid amphipod Parathemisto gaudichaudii present in larger fish indicates some predation by those fish on planktonic prey. $N$. nudifrons also preyed primarily on benthos, but more on epifauna than did $N$. gibberifrons. Although sedentary polychaetes were taken by $N$. nudifrons they were less important than for $N$. gibberifrons, and sedentary polychaete tubes and the tubes of other infauna constituted only $4 \%$ of $N$. nudifrons stomach contents. Gastropods, an epifaunal 
group, were more important prey for $N$. nudifrons than for $N$ gibberifrons. Cumaceans, an infaunal group, were present in $91 \%$ of the $N$. gibberifrons and only $28 \%$ of $N$. nudifrons; while epifaunal caprellid amphipods occurred on only $15 \%$ of the $N$. gibberifrons but in $37 \%$ of the $N$. nudifrons. Rocks and sediment, present in $86 \%$ of the $N$. gibberifrons, were found in only $29 \%$ of the $N$. nudifrons.

The different feeding modes of these two species suggest that the gammaridean amphipods and isopods preyed upon by Notothenia gibberifrons may occupy different habitats within the benthic community and belong to different taxonomic groups than those taken by $N$. nudifrons. This would make proportional prey overlap even less than that calculated using general 'gammaridean amphipod' and 'isopod' categories.

Based on small sample sizes, it appears that the minor species in the fish community also partitioned the prey resources. There were, however, some species pairs with high overlap values, all cases in which Euphausia superba was the principal prey.

Benthic prey, particularly infauna, was the major food resource supporting the fish biomass in this community, due primarily to the importance of these prey to the dominant Notothenia gibberifrons. However, euphausiids (particularly Euphausia superba but also E. crystallarophias and E. frigida) and calanoid copepods were also significant, because of their importance to $N$. larseni, Trematomus newnesi, $T$. eulepidotus, Chaenocephalus aceratus, and Champsocephalus gunneri.

Notothenia gibberifrons, N. larseni, and N. nudifrons showed no diel patterns in either stage of prey diges- tion or mean prey biomass in the stomachs. The 3 species had mean dry prey biomass values ( \pm two standard errors of the mean) of $0.152 \pm 0.018 \%$ wet and $0.623 \pm 0.074 \%$ dry body weight, $0.269 \pm$ $0.076 \%$ wet and $1.102 \pm 0.311 \%$ dry body weight, and $0.310 \pm 0.037 \%$ wet and $1.270 \pm 0.152 \%$ dry body weight, respectively, in the 6 traw samples combined.

\section{Community 5 - South Orkney Islands}

Community 5 was located at 274-305 $\mathrm{m}$ depth, $70.2 \mathrm{~km}$ from Laurie Island, South Orkney Islands (Fig. 1, Table 1). Sea surface temperature was $1.2^{\circ} \mathrm{C}$.

Eight species of fish were identified (Table 10). Three specimens in the family Liparidae were not identified because of taxonomic uncertainty with Antarctic members of this family. Species diversity was low $\left(H^{\prime}=0.702 ; e=0.293\right)$ as $84 \%$ of the individuals were Notothenia larseni. $N$. gibberifrons and $N$. kempi comprised most of the rest of the fishes. The dominant species in terms of biomass were $N$. gibberifrons and $N$. larseni. Large specimens of Champsocephalus gunneri and Chaenocephalus aceratus together comprised $22 \%$ of the biomass. Pogonophryne dolichobranchiata, Artedidraco skottsbergi, Trematomus scotti, and liparids were minor components

Specimens from all 8 identified species and the 3 unidentified liparids contained prey and were analyzed for food habits (Fig. 6). Notothenia larseni preyed primarily on calanoid copepods, with Euphausia superba increasing in importance in larger fish.

Table 10. Community 5 - South Orkney Islands. Fish community structure and number of individuals in each species for which prey were examined

\begin{tabular}{|c|c|c|c|c|c|}
\hline Species & $\begin{array}{l}\text { Number } \\
\text { captured }\end{array}$ & $\begin{array}{c}\text { Percent } \\
\text { by number }\end{array}$ & $\begin{array}{l}\text { Weight } \\
\text { captured } \\
\text { (g) }\end{array}$ & $\begin{array}{c}\text { Percent } \\
\text { by weight }\end{array}$ & $\begin{array}{c}\text { Number in } \\
\text { which prey } \\
\text { were examined }\end{array}$ \\
\hline \multicolumn{6}{|l|}{ Nototheniidae: } \\
\hline Notothenia larseni & 559 & 84.2 & 12,020 & 35.2 & 173 \\
\hline Notothenia gibberifrons & 43 & 6.5 & 12.972 & 38.0 & 41 \\
\hline Notothenia kempi & 27 & 4.1 & 1,019 & 3.0 & 27 \\
\hline Trematomus scotti & 4 & 0.6 & 119 & 0.3 & 3 \\
\hline \multicolumn{6}{|l|}{ Channichthyidae: } \\
\hline Chaenocephalus aceratus & 13 & 2.0 & 2,203 & 6.5 & 7 \\
\hline Champsocephalus gunneri & 9 & 1.4 & 5,108 & 15.0 & 9 \\
\hline \multicolumn{6}{|l|}{ Harpagiferidae: } \\
\hline Pogonophryne dolichobranchiata & 3 & 0.5 & 587 & 1.7 & 3 \\
\hline Artedidraco skottsbergi & 3 & 0.5 & 15 & $<0.1$ & 3 \\
\hline Liparidae (unidentified) " & 3 & 0.5 & 57 & 0.2 & 3 \\
\hline Total & 664 & & 34,100 & & 269 \\
\hline Probably different species & & & & & \\
\hline
\end{tabular}




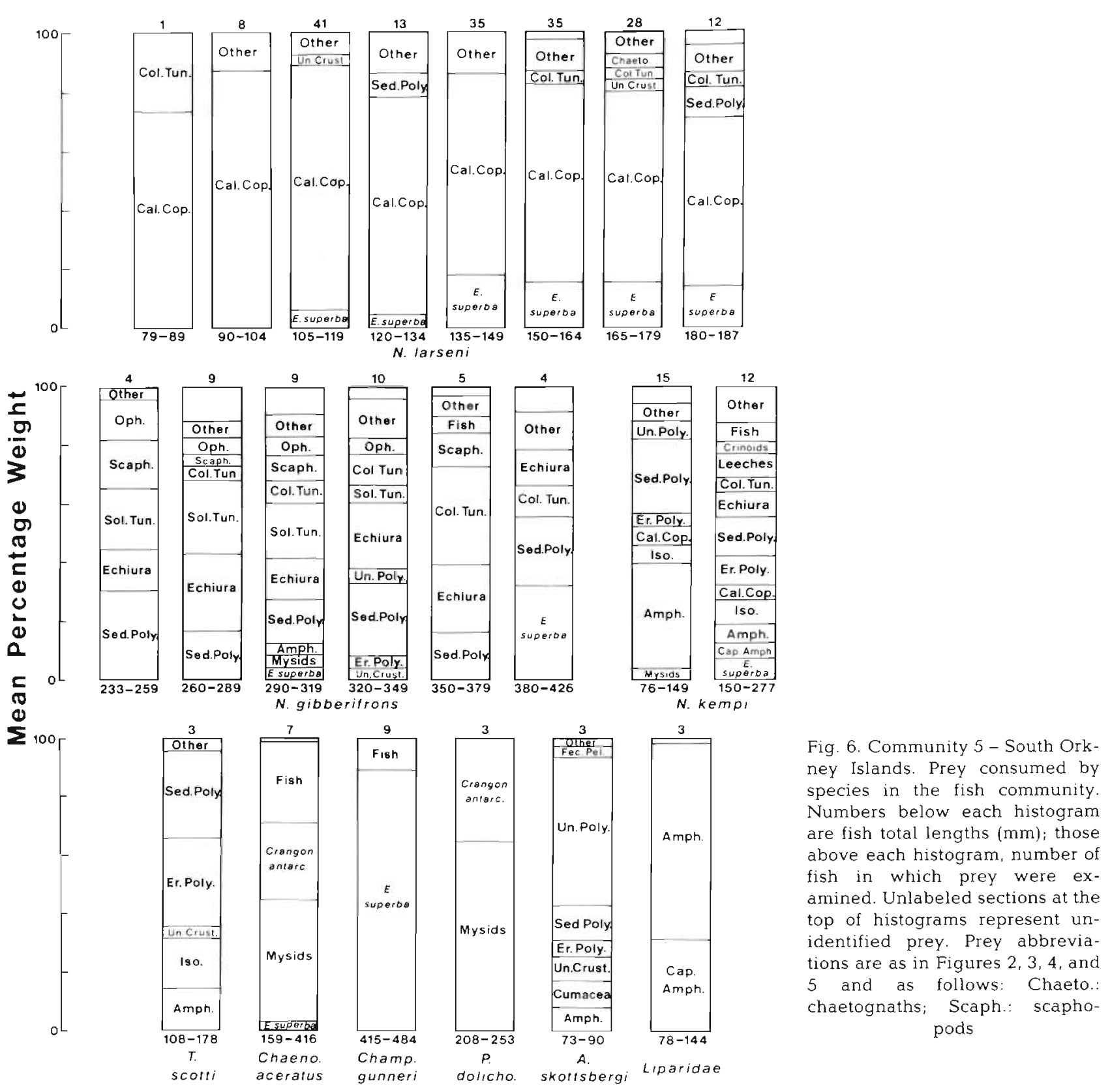

Chaetognaths were not important prey in terms of weight, but had a $30 \%$ frequency of occurrence.

Notothenia gibberifrons preyed heavily on sedentary polychaetes and echiurans. A large portion of the echiuran biomass consumed by fish in the 3 smallest size groups consisted of only echiuran probosci, or feeding gutters. Echiurans are infaunal organisms which project their proboscis onto the sediment surface for feeding. The feeding gutters were likely bitten off while in that position. Most echiuran biomass consumed by fish in the 3 largest size groups was whole animals, although some separate gutters were found. Benthic solitary tunicates and ophiuroids were impor- tant prey for fish in the smaller size groups, and benthic colonial tunicates increased as prey with increasing fish size. Scaphopods were taken by fish in nearly all size groups.

Notothenia kempi in the smaller size group preyed primarily on gammaridean amphipods and sedentary polychaetes. Fish in the larger size group had a very diverse diet, taking several crustacean and worm groups, benthic colonial tunicates, leeches, crinoids, and fishes in approximately equal proportions.

The other species were captured in only small numbers and changes in food habits accompanying growth could not be analyzed (Fig. 6). 
Table 11. Community 5 - South Orkney Islands. Proportional prey overlap $\left(C_{i h}\right)$ between fush species

\begin{tabular}{|c|c|c|c|c|c|c|c|c|}
\hline & $\begin{array}{l}\text { N.gib- } \\
\text { berifrons }\end{array}$ & $\begin{array}{c}N \\
\text { kempi }\end{array}$ & $\begin{array}{c}T \\
\text { scotti }\end{array}$ & $\begin{array}{l}\text { Chaeno. } \\
\text { aceratus }\end{array}$ & $\begin{array}{l}\text { Champso. } \\
\text { gunneri }\end{array}$ & $\begin{array}{c}P \\
\text { dolicho. }\end{array}$ & $\begin{array}{c}\text { A. } \\
\text { skotts. }\end{array}$ & Luparidae \\
\hline Notothenia larseni & 166 & .218 & .098 & .050 & 124 & 018 & .100 & 027 \\
\hline Notothenia gibberifrons & & .429 & .280 & .056 & .062 & .012 & 200 & .062 \\
\hline Notothenia kempi & & & .524 & 106 & .067 & .042 & 345 & .278 \\
\hline Trematomus scotti & & & & .018 & .018 & .003 & .308 & 157 \\
\hline Chaenocephalus aceratus & & & & & 142 & .679 & .016 & .008 \\
\hline Champsocephalus gunneri & & & & & & .000 & .000 & .006 \\
\hline Pogonophryne dolichobranchiata & & & & & & & .016 & .002 \\
\hline Artedidraco skottsbergi & & & & & & & & .090 \\
\hline
\end{tabular}

Members of this fish community clearly partitioned the prey resources. Proportional prey overlap values were less than 0.500 in all but two cases (Table 11). Thus, although most prey were identified only to general taxonomic group, identification at this level was sufficient to demonstrate the partitioning of prey resources.

A majority of the community prey resource partitioning, that by the dominant Notothenia larseni and $N$. gibberifrons, was due to morphological and behavioral adaptations for feeding in different habitat zones within the community. $N$. larseni preyed on planktonic crustacea. $N$. gibberifrons had a benthic feeding mode taking infauna such as sedentary polychaetes, echiurans, and scaphopods. N. kempi, although not a dominant species, was the third most numerically abundant. This species has a mouth and body form similar to $N$. nudifrons, and also had a benthic feeding mode. $N$. kempi preyed more on epifauna and less on. infauna than $N$. gibberifrons did. Rocks and sediment were present in only $15 \%$ of the N. kempi compared to $78 \%$ of the $N$. gibberifrons.

Sample sizes of the other fish species in the community were low, but it appears there was substantial prey resource partitioning by these species also. There was, however, a high degree of prey overlap between Chaenocephalus aceratus and Pogonophryne dolichobranchiata, primarily due to mysids. The mysid prey may be locally abundant, making competition for this resource minimal. There was also a moderate amount of prey overlap between Notothenia kempi and Trematomus scotti, but since $I$ scotti was such a minor component of the fish community, potential competition would be minimal. Planktonic crustaceans were the major prey resources supporting fish biomass at this community, due primarily to the importance of calanoid copepods to $N$. larseni, and of Euphausia superba to Champsocephalus gunneri and N. Larseni. Benthic prey groups, particularly infauna, were important too, because of their significance to the diet of $N$. gibberifrons

Notothenia larseni and $N$ gibberifrons showed no diel patterns in either stage of prey digestion or prey biomass in the stomachs. These two species had mean dry prey biomass values ( \pm two standard errors of the mean) of $0.258 \pm 0.031 \%$ wet and $1.057 \pm 0.127 \%$ dry body weight and $0.200 \pm 0.033 \%$ wet and $0.820 \pm$ $0.135 \%$ dry body weight, respectively, in the six trawl samples combined.

\section{Daily Rations}

Daily rations were calculated for Notothenia angustifrons, $N$ gibberifrons, and $N$. larseni using their gastric evacuation rates (from Crawford and McCleave, in press) and the mean dry prey biomass found in these species over a $24 \mathrm{~h}$ cycle in the present study. Gastric evacuation rates, determined at $1^{\circ} \mathrm{C}$, are $2.7 \%, 1.6 \%$, and $4.9 \%$ of ash-free dry matter in the stomach evacuated per hour by $N$, angustifrons, $N$. gibberifrons, and $N$. larseni, respectively (Crawford and McCleave, in press). Daily rations were calculated twice for $N$. gibberifrons and $N$. larseni, once using the lowest prey biomass value found in the present study and once using the highest. The following are the daily rations, in terms of dry prey biomass consumed per day, expressed as a percentage of (A) wet body weight and (B) dry body weight:

$\begin{array}{llll} & & (\mathrm{A}) & \\ \text { Notothenia angustifrons } & \text { (Community 3) } & 0.247 & 1.012 \\ \text { N. gibberifrons } & \text { (Community 4) } & 0.058 & 0.238 \\ \text { N. gibberifrons } & \text { (Community 2) } & 0.147 & 0.602 \\ \text { N. larseni } & \text { (Community 5) } & 0.303 & 1.242 \\ \text { N. larseni } & \text { (Community 1) } & 0.495 & 2.029\end{array}$

\section{Importance of Krill as Prey}

Adult krill was an important food source for several fish species. Euphausia superba comprised $74.9 \%$ and $41.0 \%$ of the prey biomass of $N$. larseni from Communities 1 and 4 , respectively. In terms of daily krill consumption this represents $1.520 \times 10^{-2}$ and $0.531 \times$ 
$10^{-2} \mathrm{~g}$ dry wt of krill consumed $\mathrm{g}^{-1}$ dry body wt $\mathrm{d}^{-2}$ by N. larseni in Community 1 and 4, respectively. Champsocephalus gunneri also preyed heavily on krill. Euphausia superba comprised $75.3 \%$ of the prey biomass of the $C$. gunneri from Communities 1, 2, 4 , and 5 combined. Trematomus newnesi in Community 4 consumed $48.9 \%$ E. superba and $11.4 \%$ E. crystallarophias. The single Pseudochaenichthys georgianus in Community 1, the one Champsocephalus esox in Community 2 , and the three $T$. hansoni in Community 2 had $95.3 \%, 90.3 \%$, and $79.5 \%$, respectively, of their prey composed of $E$. superba. The three Chaenocephalus aceratus in Community 4 had $66.4 \%$ of prey biomass composed of E. superba, and another $17.1 \%$ was identifiable only as either euphausiids or mysids. The three $C$. aceratus from Community 1 and seven from Community 5, however, had not preyed appreciably on krill.

\section{DISCUSSION}

\section{Community Structure}

It is known that the Antarctic has comparatively few fish species. The entire Antarctic Region, that area south of the Antarctic Convergence, has only $\sim 110$ species of coastal fishes (DeWitt, 1971; Permitin, 1977). There have been no previous studies on species diversity within Antarctic fish communities. The present investigation has shown that benthic fish communities at South Georgia Island, the South Sandwich Islands, and the South Orkney Islands have low species diversity. Thirteen or fewer fish species were present in all communities. The $H^{\prime}$ diversity values were less than 1.3 in all cases and less than 0.8 in 3. The evenness values were less than 0.6 in all communities and less than 0.3 in 3 . The low $H^{\prime}$ values reflect low numbers of species and the pronounced dominance of 3 or fewer species in all communities. These values contrast with those of tropical fish communities which can contain 100 to 200 species (Goldman and Talbot, 1976) and have $H^{\prime}$ diversity values between 2 and 3 (Molles, 1978) or even $>3$ (Smith and Tyler, 1972).

The South Sandwich Island community had a particularly low species diversity with only 5 fish species present and $>96 \%$ of both number and biomass being Notothenia angustifrons. Several factors likely contribute to the very low diversity. This island group is geographically isolated from other Antarctic land masses (Fig. 1). Also, these islands are geologically young volcanic formations and have narrow, shallow shelf zones where coastal fish communities could develop. Previous zoogeographic work has shown the
South Sandwich Island group in general to have few fish species. Permitin (1977) reported only 12 species from these islands, 8 from shallow $(<300 \mathrm{~m})$ coastal areas. The present study has added $N$. coriiceps to this list.

The dominant species in all fish communities were one or more of the nototheniids Notothenia larseni, $N$. gibberifrons, $N$. angustifrons, and $N$. nudifrons. Thus, dominance of the family Nototheniidae in terms of number of species in the Antarctic (DeWitt, 1971; Permitin, 1977) is also reflected in the number of individuals and biomass of fishes within these five communities.

Sampling with the large trawl used in this study failed to collect individuals of any species $<40 \mathrm{~mm}$ total length, and fishes $<70 \mathrm{~mm}$ long were not often caught. Small fishes were likely not retained by the net. There is also the possibility that large fishes - such as large channichthyids, Notothenia gibberifrons, or Parachaenichthys georgianus - avoided the net. However, the stationary defensive posture assumed by channichthyids and nototheniids when approached by a diver (Robilliard and Dayton, 1969) suggests that trawl avoidance was not a substantial problem. Despite a lack of the smallest individuals, there was striking consistency in species composition and relative abundance among trawl samples taken in each community. It is felt that the community structure descriptions accurately represent the relative abundance of fishes in these communities.

\section{Trophic Ecology}

From analyses of trophic ecology, some general trends are apparent in the pattern of resource partitioning in Antarctic fish communities. Apart from the somewhat special situations in Communities 2 and 3, a high degree of food resource partitioning is evident even though most prey were identified only to general taxonomic group. Dominant fishes partitioned the prey resources by morphological and behavioral adaptations for feeding at different vertical levels within the community. Notothenia larseni is a pelagic feeder preying on Euphausia superba and mysids at South Georgia Island, and on calanoid copepods, E. superba, and chaetognaths at the South Orkney Islands. $N$. gibberifrons is a benthos feeder preying primarily on infaunal organisms such as sedentary polychaetes, echiurans, sipunculids, and priapulids. Daniels (in press) observed $N$. gibberifrons feeding and described it as a 'slurp feeder', sucking up and sorting through muddy sediments, consuming prey and incidental small rocks and sediment. This feeding behavior explains why rocks and sediment were frequently found 
in $N$. gibberifrons in the present study. $N$. nudifrons is also a benthos feeder, but preys more in epifauna (prey on the bottom sediments, on sponges or bryozoans, etc., or active near the bottom) than on infauna. Prey such as gammaridean amphipods, isopods, Crangon antarcticus, Chorismus antarcticus, tanaids, and gastropods were taken. $N$. nudifrons and $N$. gibberifrons do not have complete separation of feeding modes, but morphological and behavioral differences function to separate their feeding niches to a large degree. $N$. angustifrons was present in only Communities 2 and 3 , both of which had somewhat special trophic ecology. However, it appears that $N$. angustifrons has a feeding mode closely associated with the bottom sediments, since rocks and sediment were present in most fish. $N$. angustifrons and $N$. gibberifrons partitioned non-E. superba prey in Community 2, suggesting differences in feeding biology in these two species.

Notothenia larseni, N. gibberifrons, and $N$ nudifrons all had consistent feeding modes from community to community, although specific prey groups changed. It seems likely that these species consume generally whatever prey is available in the particular habitat zone in which they feed.

Schoener (1974) stated that habitat separation is important more often than either within-habitat prey separation or temporal separation in avoiding food resource overlap. The few (1-3) dominant species in each community in the present study partitioned the prey resources along a vertical distribution axis. Vertical differences in feeding zones resulted in low prey overlap, except in the community where all fishes had converged on an abundant and available krill and mysid resource. It is likely that feeding niche differences were evolved, and the communities structured in this way, as an adaptation to reduce or avoid competition for prey resources. Because of low fish diversity, no fine division of within-habitat food resources was necessary. This contrasts with tropical fish communities in which there are commonly many species feeding in the same habitat, partitioning the food resource dimension (e.g. Hiatt and Strasburg, 1960) The fact that species in the family Notothenidae have evolved niche differences allowing the exploitation of prey in different habitats may be a contributing factor to their dominance in all fish communities in the present study. This may also contribute to the success of nototheniids, in terms of number of species, in the Antarctic

Nearly all cases of very high prey overlap by fishes in these communities were cases involving nondominant species, and in which krill or to a lesser extent mysid prey was important for both species. It is speculated that krill, and likely also mysids, occur locally in high concentrations, minimizing competition for these prey, and allowing utilization by several fish species. This is particularly true during austral summer and fall (after summer phytoplankton blooms) when these communities were sampled. The channichthyid species all fed above the bottom on Euphausia superba, fishes, or mysids. Because a large part of their diets was E. superba, competition for prey among the members of this family and with nototheniids was minimal.

It is felt that any designation of the fishes in these communities as either specialist or generalist feeders would merely be a reflection of the diversity of prey resources in the habitat zone where a particular species is adapted to feed. Thus, pelagic feeders had less diverse diets than benthic feeders because of the lower diversity of pelagic compared to benthic prey.

The relative importance of planktonic vs benthic prey resources to a particular fish community depended generally on the feeding modes of the dominant fish species. However, at Community 2 Euphausia superba and mysids were consumed in substantial amounts by nearly all fishes despite their feeding mode; and at Community 3, South Sandwich Islands, the fishes were supported almost entirely by 3 species of gammaridean amphipods. The trophic ecology of these fish communities is discussed in detail below.

Community 2, South Georgia Island, illustrates a situation in which all fishes in the community consumed Euphausia superba and, to a lesser extent, the mysid Antarctomysis maxima. E. superba, is an abundant prey resource in the Antarctic. Shoals of krill occur primarily in the euphotic zone usually within $40 \mathrm{~m}$ of the surface, seldom below 70-90 m (Makarov et al., 1970). It is probable that at Community 2 a shoal of krill had moved inshore, close to the island, and because of the shallow water at this location, was forced close to or actually onto the bottom. Thus, fishes which have benthic feeding modes, even Notothenia gibberifrons which is primarily an infauna feeder, preyed substantially on krill. It is speculated that a concentration of mysids was also present near or on the bottom. Convergence of more than one fish species to feed on a particular prey resource when it is abundant has been observed in other fishes (e. g. Harrington and Harrington, 1961; Keast, 1978). Community 2 is the only community in which the dominant fish species had high prey overlap values, additional evidence for the non-limiting nature of the krill and mysid prey.

Community 3, South Sandwich Islands, had the lowest fish species diversity and a prey spectrum consisting almost entirely of only 3 gammaridean amphipod species. The narrow shelf zone, geologically recent formation, and remoteness of this island group all contribute to the low fish diversity. However, because 
several fish species in the other communities do occur in the South Sandwich Island group, limited prey diversity was likely a major factor contributing to low diversity within this fish community. The sediment at this location consisted of small volcanic rocks and cinders, continually being built up and generally unstable. Little organic sediment was present. Because of this bottom type, there was a poorly developed benthic invertebrate fauna and gammaridean amphipods may have been the only major prey available when no krill shoals were present. Competition for the few amphipod species was likely great and low diversity of fishes reflects this low prey resource diversity. A similar pattern seems to exist at nearshore trawling sites elsewhere in the South Sandwich Islands. Either Notothenia angustifrons or N. larseni dominated these samples and either gammaridean amphipods, or amphipods and Euphausia superba were major prey.

No previous studies have examined the trophic ecology of Antarctic fish communities. The only investigations which have compared the feeding biology of Antarctic fishes utilized specimens collected at various times and from often widely separated geographic areas. These studies report a higher diversity of prey than would be consumed by individuals at one particular location and time. Such analyses provide information on the general feeding niche of individual species but give no information on species interactions and food resource partitioning by fishes within communities preying from the same food resource base. Thus, the only studies which can be compared with the present work are investigations of fishes collected over several years around South Georgia Island (Permitin and Tarverdiyeva, 1972) and the South Orkney Islands (Permitin and Tarverdiyeva, 1978), and fishes collected along the Antarctic Peninsula (Daniels, in press). The overall feeding trends of fishes are in general agreement with the present investigation. That is, Notothenia larseni preyed on plankton, and N. gibberifrons and $N$. nudifrons on benthos. Daniels (in press) distinguished between errant and sedentary polychaetes and reported that $N$. gibberifrons fed more on sedentary polychaetes and $N$. nudifrons more on errant. The channichthyids Chaenocephalus aceratus, Champsocephalus gunneri, and Pseudochaenichthys georgianus were characterized as Euphausia superba, fish, and mysid feeders.

The prey overlap values reported by Permitin and Tarverdiyeva $(1972,1978)$ and Daniels (in press) represent only the similarity in feeding mode between species collected at various locations and times. They are not overlap values reflecting interaction among fishes within a community, feeding from the same resource base. They do, however, show that in most cases where species pairs had high degrees of similar- ity in feeding biology, Euphausia superba or in the Antarctic Peninsula fishes E. superba and E. crystallarophias were the major prey items. This is similar to findings of the present study within fish communities. Permitin and Tarverdiyeva $(1972,1978)$ (using percentage frequency of occurrence as the means of describing prey) found moderate to high levels of prey similarity among Notothenia gibberifrons, $N$. nudifrons, and N. kempi. Daniels (in press) however (using relative prey volumes, and distinguishing between sedentary and errant polychaetes) found differences between $N$. gibberifrons and $N$. nudifrons. He did not collect $N$. kempi

A substantial amount of the benthic invertebrate biomass at all communities, except the South Sandwich Islands community, consisted of one or more of the following groups: large sponges, bryozoans, tunicates, and ophiuroids. These animals were generally not preyed upon, except for the solitary and colonial tunicates taken by Notothenia gibberifrons in the two South Orkney Island communities. Andriashev (1965) also noted the importance of sponges, tunicates, and bryozoans in the Antarctic benthos, and concluded that most benthic invertebrate biomass was inedible by fishes. The present study has shown that tunicates are utilized as prey.

Notothenia gibberifrons, $N$. nudifrons, $N$. larseni, and $N$. angustifrons were all captured in sufficient abundance in each of the 6 trawl samples taken per community to allow an examination of feeding chronology. No diel differences in feeding intensity were found. This does not necessarily mean that feeding was continuous or randomly distributed over a $24 \mathrm{~h}$ period. In fact this was likely not the case. Any diel feeding periodicity was probably undetectable because of slow stomach evacuation rates (between 50 and $150 \mathrm{~h}$ ) (Crawford and McCleave, in press). Stage of prey digestion and prey biomass present in the stomachs of these species did show some variation among trawl samples but the variation was usually not great and had no diel pattern. Consequently, the prey biomass values from all 6 trawl samples in each community were combined and mean prey biomass present over a $24 \mathrm{~h}$ period calculated for each species. These values were used to calculate daily rations. Because of the lack of diel prey weight differences, the daily ration formula $\mathrm{R}_{\mathrm{T}}=24 \overline{\mathrm{S}} \alpha$ was used. The daily rations calculated for $N$. angustifrons, $N$. gibberifrons, and $N$. larseni are less then those reported for two other Antarctic fishes by Tarverdiyeva (1972). N. rossii was reported to consume, on a wet prey weight basis, $13.9 \%$ and Dissostichus eleginoides $5.1 \%$ of wet body weight $\mathrm{d}^{-1}$ at $1.2^{\circ}-1.3^{\circ} \mathrm{C}$. These values were determined using techniques subject to several sources of variability and error (some of which were discussed by 
the author) and therefore should be viewed with caution. The daily rations calculated in the present study are, however, in general agreement with the wet prey weight value of $0.87 \%$ wet body weight $d^{-1}$ reported for Atlantic cod (Gadus morhua) at $2{ }^{\circ} \mathrm{C}$ (Tyler, 1970).

Several species of fish were previously known to consume krill (Olsen, 1955; Everson, 1970; Permitin, 1970; Permitin and Tarverdiyeva, 1972, 1978), but data were generally qualitative. The present study has shown quantitatively that krill is an important food resource for Notothenia larseni, Champsocephalus gunneri, Trematomus newnesi, and Chaenocephalus aceratus. Based on smaller sample sizes, T. hansoni, Champsocephalus esox and Pseudochaenichthys georgianus also appear to prey heavily on Euphausia superba. It was also shown, in Community 2, that essentially all fishes, even those with benthic feeding modes, will take advantage of abundant krill resources when conditions are such that the krill are available close to the bottom. A similar finding was reported for Atlantic cod in Balsfjorden, northern Norway (Pearcy et al., 1979). When swarms of the euphausiids Thysanoessa inermis and $T$. raschii occurred close to or on the bottom, benthic cod were found to feed primarily on these krill.

This investigation has added substantially to our understanding of trophic ecology and structure of Antarctic benthic fish communities. There are, however, several areas which need further study. Data are needed on seasonal aspects of feeding. The present study examined summer and late fall feeding biology, and information is needed on winter feeding in Antarctic fishes. This would be difficult but would provide data on the importance of planktonic prey, particularly Euphausia superba, to fishes under the temporary ice sheet. Additional communities from other geographic areas should also be examined. More work on evacuation rates of Antarctic fishes is necessary to give information on daily rations and to quantify krill consumption in terms of biomass per gram fish per day. Other than work on Notothenia neglecta at Signy Island, South Orkney Islands (Everson, 1970) there are no reliable estimates of the biomass and productivity of Antarctic fish stocks. This information is essential in order to quantify prey consumption in terms of fish populations and geographic areas, and thus to further understand the impact of fishes on various prey resources in the Antarctic ecosystem.

Acknowledgements. I thank all the people who helped with the collecting of fishes on Antarctic cruises 0575 and 0876 aboard the ARA 'Islas Orcadas'. In particular I thank Drs J. D. McCleave, H. H. DeWitt, J. H. Dearborn, R. R. Eakin, R. E. Crawford, Mr R. F. Shaw, and Mr. J. T Konecki. The expertise and cooperation of the Argentine Naval Hydrographic Service captain and crew is acknowledged. Special thanks go to $\mathrm{Mr}$ D. M. Wyanski whose conscientious help on nearly every phase of this study made progress more efficient, organized, and rapid. I thank Dr C. F. E. Roper of the US National Museum for identifying octopods. I thank Dr. J. H. Dearborn for aid in identifying prey organisms, and Ms. A. M. Stevens and Mr. A. D. Rhodes for assistance with sorting and weighing prey organisms. I am grateful to Ms. H. Holman and Dr. L. E. Watling for identifying amphipods from the South Sandwich Islands. Thanks also go to Mr. J. H. Power for much help with computer analyses of the data, particularly with use of the SPSS system. I thank Drs J. D. McCleave, H. H. DeWitt, J. H. Dearborn, W. E. Glanz, and M. S. Tyler at the University of Maine; M. R. Gilligan at Savannah State College; and D. W Menzel and G.-A. Paffenhöfer at Skidaway Institute of Oceanography for constructive comments on the manuscript. I am grateful to my wife. Dr. Nancy $M$. Targett, for her optimism, enthusiasm, and help throughout this study. Computer time was fumished by the Computing and Data Processing Services, University of Maine. This research was funded by the National Science Foundation under Grants OPP 74-08565 and DPP 76-23043 and by the Faculty Research Funds Committee of the University of Maine.

\section{LITERATURE CITED}

Andriashev, A. P. (1965). A general review of the Antarctic fish fauna. In: van Mieghem, J., van Oye, P. (eds) Biogeography and ecology in Antarctica. Dr. W. Junk Publishers, The Hague, pp. 491-550

Arnaud, P., Hureau, J. C. (1966). Régime alimentarie de trois Téléostéens Nototheniidae antarctiques (Terre Adélie). Bull. Inst. Océanogr. Monaco 66: 1-24

Colwell, R. K., Futuyma, D. J. (1971). On the measurement of niche breadth and overlap. Ecology 52: 567-576

Crawford, R. E., McCleave, J. D. (in press). Gastric evacuation rates in four Antarctic fishes of the genus Notothenia. Mar Biol.

Daniels, R. A. (in press). Feeding ecology of fishes of the Antarctic Peninsula. Fish. Bull. U.S.

DeWitt, H. H. (1971). Coastal and deep-water benthic fishes of the Antarctic, Antarctic Map Folio Series, Folio 15, American Geographical Society, New York

DeWitt, H. H., Hopkins, T L. (1977). Aspects of the diet of the Antarctic silverfish, Pleurogramma antarcticum. In: Llano, G. A. (ed) Adaptations within Antarctic ecosystems: Proceedings of the third SCAR symposium on Antarctic biology. Smithsonian Institution, Washington, D.C., pp. $557-567$

Eggers, D. M. (1977). Factors in interpreting data obtained by diel sampling of fish stomachs. J. Fish. Res. Bd Can. 34: 290-294

Everson, I. (1970). The population dynamics and energy budget of Notothenia neglecta Nybelin at Signy Island, South Orkney Islands. Br. Antarct. Surv. Bull. 23: 25-50

Goldman, B., Talbot, F. H. (1976). Aspects of the ecology of coral reef fishes. In: Jones, D. A., Endean, R. (eds) Biology and geology of coral reefs, 2, Biology, Vol. 3. Academic Press, New York, pp. 125-154

Harrington, R. W., Jr., Harrington, E. S. (1961). Food selection among fishes invading a high subtropical salt marsh: From onset of flooding through the progress of a mosquito brood. Ecology 42: 646-666

Hiatt, R. W., Strasburg, D. W (1960). Ecological relationships of the fish fauna on coral reefs of the Marshall Islands. Ecol. Monogr. 30: 65-127 
Holloway, H. L. (1969). Notes on the fishes collected at McMurdo Sound, Antarctica, during the austral summer of 1964-65, with information on the diets of two species. Va J. Sci. 20: 188

Hureau, J. C. (1964). Contribution à la connaissance de Trematomus bernacchij Boulenger In: Carrick, R., Holdgate, M., Prevost, J. (eds) Biologie antarctique. Hermann, Paris, pp. $481-487$

Hureau, J. C. (1966). Biologie de Chaenichthys rhinoceratus Richardson, et problème du sang incolore des Chaenichthyidae, Poissons des Mers Australes. Bull. Soc. Zool. Fr. 91: 735-751

Hureau, J. C. (1970). Biologie comparée de quelques Poissons antarctique (Nototheniidae). Bull. Inst. Océanogr. Monaco 68: $1-244$

Keast, A. (1978). Trophic and spatial interrelationships in the fish species of an Ontario temperate lake. Envir. Biol. Fish. 3: $7-31$

Laws, R. M. (1977). The significance of vertebrates in the Antarctic marine ecosystem. In: Llano, G. A. (ed.) Adaptations within Antarctic ecosystems: Proceedings of the third SCAR symposium on Antarctic biology. Smithsonian Institution, Washington, D.C., pp. 411-438

Makarov, R. R., Naumov, A. G., Shevtsov, V V (1970). The biology and the distribution of the Antarctic krill. In: Holdgate, M. W. (ed.) Antarctic ecology, Vol. 1. Academic Press, New York, pp. 173-176

McCleave, J. D., Dearborn, J. H., DeWitt, H. H. (1977). Ecology of benthic fishes and echinoderms along the Scotia Arc and the Antarctic Peninsula. Antarct. J. US. 12: 19-20

Meier, C. M. (1971). Somatometria y alimentacion natural de Harpagifer georgianus antarcticus Nybelin, en Bahia Fildes, Island Rey Jorge, Antarctica. Bol. Inst. antart. chileno 6: 9-12

Molles, M. C. (1978). Fish species diversity on model and natural reef patches: Experimental insular biogeography. Ecol. Monogr. 48: 289-305

Moreno, C. A., Osorio, H. H. (1977). Bathymetric food habit changes in the Antarctic fish, Notothenia gibberifrons Lönnberg. (Pisces: Nototheniidae). Hydrobiologia 55: 139-144

Olsen, S. (1955). A contribution to the systematics and biology of Chaenichthyid fishes from South Georgia. Nytt Mag. Zool. 3: 79-93

Pearcy, W. G., Hopkins, C. C. E., Gronvik, S., Evans, R. A. (1979). Feeding habits of cod, capelin, and herring in Balsfjorden, northern Norway, July-August 1978: the importance of euphausiids. Sarsia 64: 269-277

Permitin, Yu. Ye. (1970). The consumption of krill by Antarctic fishes. In: Holdgate, M. W. (ed) Antarctic ecology, Vol. 1. Academic Press, New York, pp. 177-182

Permitin, Yu. Ye. (1977). Species composition and zoogeographical analysis of the bottom fish fauna of the Scotia Sea. J. Ichthyol. 17: 710-726

Permitin, Yu. Ye., Tarverdiyeva, M. I. (1972). The food of some
Antarctic fish in the South Georgia area. J. Ichthyol. 12: $104-114$

Permitin, Yu. Ye., Tarverdiyeva, M. I. (1978). Feeding of Antarctic cods (Nototheniidae) and ice-fishes (Chaenichthyidae) near the South Orkney Islands. Biol. Morya (Vladivost.) 2: 75-81

Pielou, E. C. (1966). The measurement of diversity in different types of biological collections. J. Theor. Biol. 13: 131-144

Rakusa-Suszczewski, S., Piasek, A. (1973). Size, feeding and action of proteolytic enzymes in the Antarctic fish of Trematomus genus (Notothenidae). Bull. Acad. Pol. Sci. cl. II Sér Sci. Biol. 21: 139-144

Richardson, M. G. (1975). The dietary composition of some Antarctic fish. Br Antarct. Surv. Bull. 41/42: 113-120

Robilliard, G. A., Dayton, P. K. (1969). Notes on the biology of the chaenichthyid fish Pagetopsis macropterus from McMurdo Sound, Antarctica. Antarct. J. US 4: 304-306

Schoener, T. W. (1974). Resource partitioning in ecological communities. Science, N.Y. 185: 27-39

Shannon, C. E., Weaver, W. (1949). The mathematical theory of communication, University of Illinois Press, Urbana

Showers, W. J., Jr., Daniels, R. A., Laine, D. (1977). Marine biology at Palmer Station, 1975 austral winter. Antarct. J. US 12: 22--25

Smith, C. L., Tyler, J. C. (1972). Space resource sharing in a coral reef fish community. In: Collette, B. B., Earle, S. A. (eds) Results of the Tektite program: Ecology of coral reef fishes. Los Angeles Co. Mus. Nat. Hist. Sci. Bull., Vol. 14, pp. $125-170$

Tarverdiyeva, M. I. (1972). Daily food consumption and feeding pattern of the Georgian cod (Notothenia rossif marmorata Fischer) and the Patagonian toothfish (Dissostichus eleginoides Smitt) (Fam. Nototheniidae) in the South Georgia area. J. Ichthyol. 12: 684-692

The Oceanic Society. (1980). The Southern Ocean convention workshop on management of Antarctic marine living organisms. Center for Environmental Education, Washington, D.C.

Tomo, A. (1969). Taxonomia y biologia de los peces costeros de Puerto Paraiso (Costa de Danco, península Antártica). Contrines Inst. antart argent. 110:4-18

Tyler, A. V. (1970). Rates of gastric emptying in young cod. J. Fish. Res. Bd Can. 27: 1177-1189

US Department of State. (1978). Final environmental impact statement for a possible regime for conservation of Antarctic living marine resources. Bureau of Oceans and International Environmental and Scientific Affairs, US Department of State, Washington, D.C.

Vinogradov, A. P. (1953). The elementary chemical composition of marine organisms, Efron, J., Setlow, J. K. (translators), Yale University Press, New Haven

Wyanski, D. M., Targett, T E. (in press). Feeding biology of fishes in the endemic Antarctic Harpagiferidae. Copeia

Yukhov, V. L. (1971). The range of Dissostichus mawsoni Norman and some features of its biology. J. Ichthyol. 11: $8-18$ 